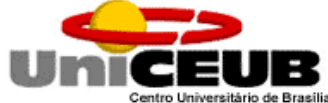

Centro Universitário de Brasília - UniCEUB

Faculdade de Tecnologia e Ciências Sociais Aplicadas - FATECS

Curso de Engenharia Civil

\author{
SÉRGIO JÚNIO SAMPAIO OLIVEIRA
}

\section{SIMULAÇÃO DE QUALIDADE DE ÁGUA DO LAGO PARANOÁ}

Brasília-DF 


\section{$-$}

Centro Universitário de Brasília - UniCEUB

Faculdade de Tecnologia e Ciências Sociais Aplicadas - FATECS

Curso de Engenharia Civil

\section{SIMULAÇÃO DE QUALIDADE DE ÁGUA DO LAGO PARANOÁ}

Orientador: Professor Dr. Bruno Collischonn

Brasília 


\title{
SIMULAÇÃO DE QUALIDADE DE ÁGUA DO LAGO PARANOÁ
}

\section{Sérgio Júnio Sampaio Oliveira - UniCEUB, PIBIC Institucional, aluno bolsista}

sergiojunio5@gmail.com

\author{
Bruno Collischonn - UniCEUB, professor orientador \\ bruno.collischonn@uniceub.br
}

O Lago Paranoá é um reservatório artificial, situado na área urbana de Brasília (DF), que conta com diversos usos de água, como navegação, recreação, geração de energia e diluição de efluentes. Atualmente, encontra-se em vias de fornecer água também para o abastecimento público da cidade, devido à crise hídrica que atinge os demais mananciais. Devido à inter-relação entre aspectos de quantidade e qualidade da água, toda nova captação de água afeta também sua qualidade. No presente trabalho, desenvolveu-se um modelo unidimensional de qualidade de água para o Lago Paranoá, usando-se o software HEC-RAS, com objetivo de obter uma ferramenta para avaliação de cenários de uso e tomada de decisão. Para a elaboração do modelo, utilizaram-se dados de diversas empresas e órgãos públicos, como CAESB, ADASA, CEB e ANA. Mesmo considerando as incertezas inerentes a qualquer modelo computacional, a calibração do modelo apresentou resultados satisfatórios. Uma vez calibrado, foram simulados alguns cenários de uso futuro do lago, notadamente as captações pretendidas no braço do ribeirão do Torto e no Ribeirão Bananal, de forma a avaliar que impacto essas captações causam na qualidade de água do lago. Entende-se que a ferramenta pode ser bastante útil em avaliações prospectivas como essa, bem como de outros tipos de alterações climáticas, hidrológicas ou antrópicas.

Palavras Chaves: Modelo de qualidade de água; Abastecimento; Lago Paranoá; Qualidade de água; HEC-RAS 


\section{AGRADECIMENTOS}

Gostaria de agradecer a todos aqueles que contribuíram direta e indiretamente e deram seus votos de apoio para esta pesquisa ser realizada. Em especial ao professor orientador Dr. Bruno Collischonn pela sua motivação, paciência e grandes ensinamentos valiosos durante todo este ano de pesquisa. Também aos engenheiros da CAESB por serem atenciosos e pelas contribuições, disponibilizando os dados imprescindíveis para realização deste trabalho. Meus mais sinceros agradecimentos a todos!

Espero que este trabalho possa ser útil aos futuros pesquisadores, estudantes e interessados sobre este tema. E que contribuía para se entender a suma importância do recurso mais essencial do planeta: $A$ água. 


\section{LISTA DE FIGURAS}

Figura 1. Monitoramento de fósforo nos principais afluentes do lago (Liporoni, 2012) . 3

Figura 2. Temperatura do Lago nas diferentes profundidades (Liporoni, 2012). 4

Figura 3. Oxigênio Dissolvido no lago de acordo com as épocas do ano (Liporoni, 2012).

Figura 4. Fluxograma de interrelação entre nutrients no modelo HEC-RAS

Figura 5. Modelo de elevação do fundo do lago Paranoá e traçado das seções

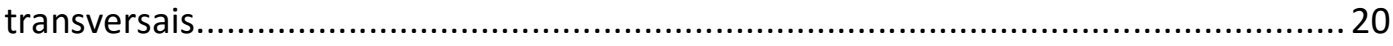

Figura 6. Topologia do lago Paranoá no modelo HEC-RAS ...................................... 20

Figura 7. Seção transversal obtida a partir da batimetria do Lago Paranoá, para entrada

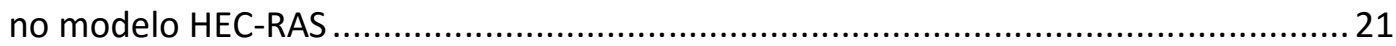

Figura 8. Localização das estações fluviométricas utilizadas ..................................... 22

Figura 9. Correlação entre vazões diárias no Riacho Fundo e nos Córregos Gama e Cabeça de Veado, usada para preencher as falhas de medição no Riacho Fundo .................... 23

Figura 10. Níveis mínimos determinados pela ADASA para o Lago Paranoá.................. 24 Figura 11. Histórico de níveis d'água do Lago Paranoá junto à barragem, disponibilizado

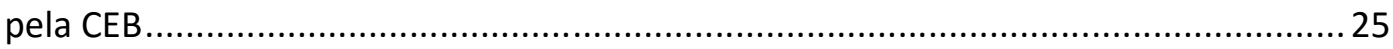

Figura 12. Comparação da radiação estimada com a radiação medida na estação do

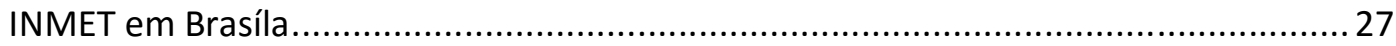

Figura 13. Exemplo da interpolação dos dados de qualidade de água e do preenchimento

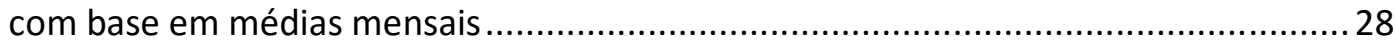

Figura 14. Medições de clorofila-a no ribeirão Bananal ............................................... 29

Figura 15. Série diária para a concentração de nitrogênio total na ETE Norte. Note-se os patamares resultantes da adoção da média mensal................................................ 31

Figura 16. Representação esquemática da ponderação das medições no ponto $C$ ao

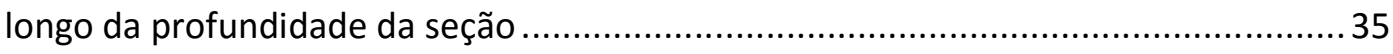

Figura 17. Lançamento da drenagem ao lado da ETE Sul, por meio de duas galerias

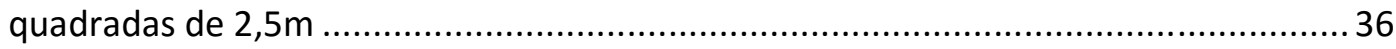

Figura 18. Lançamento de drenagem pluvial ao lado do IBAMA ...................................37 
Figura 19. Galerias de seção retangular, lançamento próximo ao parque Olhos d'água

Figura 20. Representação no HEC-RAS da captação de água no braço do Torto

Figura 21. Comparação entre temperatura da água no ribeirão Bananal e no braço do Bananal, mostrando o efeito de aumento da temperatura causado pelo Lago 41

Figura 22. Resultados para o parâmetro temperatura no braço do Bananal (ponto E3 Minas Tênis)

Figura 23. Resultados do modelo para temperatura próximo à barragem do Paranoá (ponto C).

Figura 24. Ajuste do oxigênio dissolvido no braço do Torto (e) e próximo à barragem (d)

Figura 25. Resultados para o parâmetro DBO próximo à barragem ............................. 44

Figura 26. Resultados para a concentração de algas próximo à barragem ................... 45

Figura 27. Resultados do modelo junto à barragem e limite da classe 1 ......................46

Figura 28. Resultados para o nitrato no ponto próximo à barragem ............................47

Figura 29. Resultado para o parâmetro fósforo total (orgânico+ortofosfato) próximo à

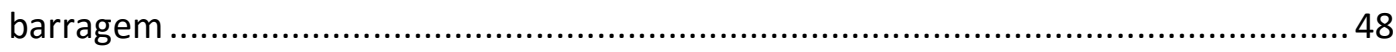

Figura 30. Impacto das captações pretendidas sobre o oxigênio dissolvido (e) e algas (d)

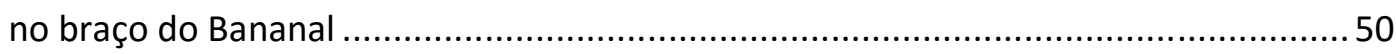

Figura 31. Impacto das captações sobre a DBO no braço do Torto (e) e sobre o fósforo orgânico próximo à barragem 


\section{LISTA DE TABELAS}

Tabela 1. Estações fluviométricas utilizadas no estudo .......................................... 22

Tabela 2. Síntese dos dados de monitoramento de qualidade de água do lago Paranoá 34

Tabela 3. Síntese dos resultados 


\section{LISTA DE ABREVIATURAS}

ADASA - Agência Reguladora de águas, Energia e Saneamento do Distrito Federal.

ANA- Agência Nacional de Águas

CAESB - Companhia de Saneamento Ambiental do Distrito Federal

CEB - Companhia Energética de Brasília

DF - Distrito Federal

HEC-RAS - Hydrologic Engineering Center's River Analysis System

NASA - National Aeronautics and Space Administration

$\mathrm{PCH}$ - Pequena Central Hidroelétrica

SRTM - Shuttle Radar Topography Mission 


\section{Introdução}

O Lago Paranoá é um reservatório artificial fortemente identificado com a cidade de Brasília, que atende a múltiplos usos de água no seu entorno. Sua construção esteve prevista desde a missão Cruls, em fins do século XIX (Sautchuk, 2014), que identificava que o barramento do rio Paranoá formaria "um lago navegável em todos os sentidos". Do ponto de vista de usos múltiplos da água, o lago é usado para recreação e lazer, navegação, geração de energia hidrelétrica na PCH Paranoá (com potência instalada de 30MW).

O Lago Paranoá atende também ao uso da sua água para diluição de efluentes domésticos tratados. Nas primeiras décadas de existência da cidade, essa prática se tornou um problema. Embora contasse com as estações de tratamento de esgoto (ETEs) Norte e Sul desde meados da década de 1960, as redes coletoras eram insuficientes, fazendo com que uma carga orgânica expressiva acabasse por ser lançada no Lago Paranoá.

Essas características acarretam sérios problemas nas primeiras décadas de existência de Brasília. Devido a problemas estruturais, uma quantidade expressiva de cargas orgânicas acabava por ser lançada no Lago Paranoá, culminando em 1978 com uma floração de algas no braço sul, com a consequente mortandade de peixes e mau cheiro (Philomeno, 2007). Isso motivou investimentos públicos em coleta e tratamento de esgoto, fazendo com que até recentemente o Lago tivesse boas condições de balneabilidade (CAESB, 2016).

Dada a localização da cidade, nas cabeceiras das maiores bacias hidrográficas do país, e portanto, distante de rios de maior porte, o Lago Paranoá se tornou uma alternativa óbvia para o atendimento à crescente demanda por água do Distrito Federal (CAESB, 2009). De fato, devido à crise hídrica, um novo uso deve ser adicionado até o fim do ano ao Lago Paranoá, que é o abastecimento humano, com as obras para a captação emergencial no braço do Torto, no Lago Norte. Além disso, está prevista uma nova captação de água no Ribeirão Bananal, que deverá reduzir a afluência ao Lago.

Os processos de quantidade e qualidade de água em rios e reservatórios são intimamente ligados, de forma que sua gestão deve ser integrada, como preconiza a legislação brasileira de recursos hídricos. Assim, uma retirada de água em qualquer ponto da bacia pode reduzir a capacidade de diluição do lago Paranoá. De fato, o uso da água do Paranoá para abastecimento tem gerado questionamentos pontuais (Congresso em Foco, 2017). Liporoni (2012) fez um trabalho pioneiro e preliminar de avaliação de impactos dessas captações sobre 
a qualidade de água do lago, usando modelagem de qualidade de água. Entretanto, dado seu caráter único de lago urbano, atendendo a múltiplos usos, é necessário ampliar o conhecimento das interrelações quali-quantitativas existentes.

Nesse contexto, um modelo matemático de qualidade de água, em que se possa fazer simulações de diferentes cenários quali-quantitativos, se constitui em uma ferramenta extremamente útil para a gestão e tomada de decisão quanto aos usos futuros da água do lago Paranoá. Naturalmente, todos os modelos possuem incertezas (Tucci, 1998), em particular os modelos de qualidade de água em reservatórios, o que não diminui seu valor como ferramenta de análise.

Portanto, o presente trabalho pretende desenvolver um modelo unidimensional de qualidade de água para o lago Paranoá, em que os processos de quantidade e qualidade da água desse importante manancial possam ser reproduzidos e as consequências de eventuais alterações antrópicas ou não possam ser avaliadas.

\section{Objetivos}

O objetivo geral deste trabalho é desenvolver um modelo matemático unidimensional de qualidade de água do Lago Paranoá, para servir como ferramenta de apoio à decisão quanto às ações relacionadas ao uso da água no entorno do lago e na bacia hidrográfica.

Como objetivos específicos, pretende-se:

a) Avaliar o impacto do aumento da demanda consuntiva de água na bacia sobre a qualidade de água do Lago Paranoá;

b) Avaliar o impacto de variações na vazão (por exemplo: decorrentes de variabilidade climática) sobre a qualidade de água do Lago Paranoá;

Entende-se que o trabalho proposto se justifica na medida em que:

a) Há poucos trabalhos na literatura dedicados à compreensão dos processos qualiquantitativos do Lago Paranoá;

b) Um modelo matemático operacional pode auxiliar na tomada de decisão quanto à locação de eventuais novos pontos de lançamento de efluentes no Lago Paranoá e na sua bacia hidrográfica, como por exemplo nos instrumentos de licenciamento ambiental e outorga de uso da água;

c) A precipitação no Distrito Federal tem mostrado irregularidades, o que poderia afetar as afluências ao Lago e consequentemente alterar as condições de qualidade de água;

d) A segmentação do reservatório em diferentes braços pode propiciar uma espacialização dos resultados de qualidade de água, permitindo a identificação de locais mais ou menos propícios a usos de contato como balneabilidade ou usos prioritários como consumo humano 


\section{Fundamentação Teórica}

\subsection{O Lago Paranoá e sua qualidade de água}

A bacia do Lago Paranoá conta com uma boa quantidade de estações de monitoramento de quantidade e qualidade de água. Isso permitiu a alguns autores realizar análises e aumentar a compreensão sobre os fenômenos que ocorrem nesse manancial.

Liporoni (2012) fez uma análise bastante aprofundada dos dados disponíveis, chegando a conclusões que são importantes no âmbito do presente trabalho.

Em primeiro lugar, merece destaque uma análise diz respeito ao caráter das cargas poluentes afluentes ao Lago Paranoá. A figura abaixo mostra a variação da concentração de fósforo ao longo de um ano, obtida de Liporoni (2012).

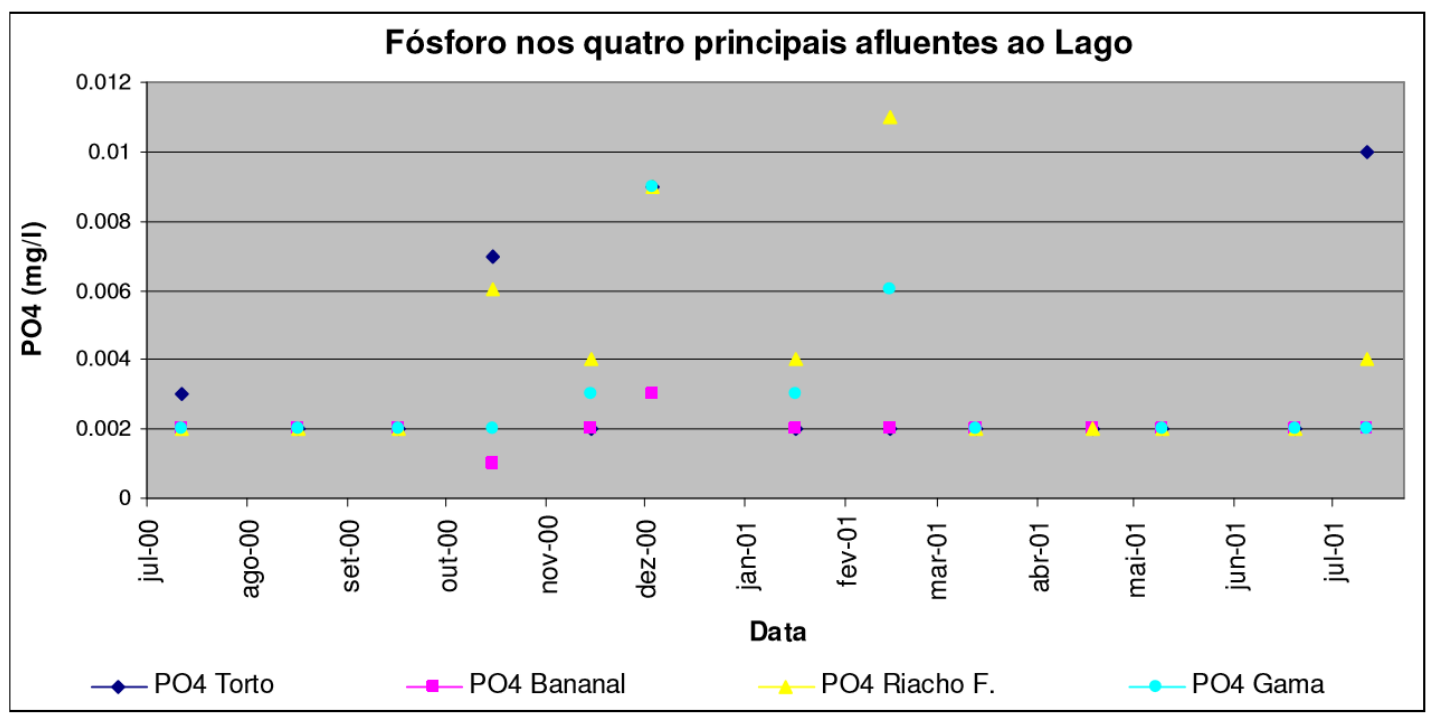

Figura 1. Monitoramento de fósforo nos principais afluentes do lago (Liporoni, 2012)

O que se pode constatar nesse gráfico é que predominam cargas difusas de poluentes, uma vez que a concentração é mais alta no período de chuvas. Essa constatação é particularmente evidente no caso do Riacho Fundo, que é a sub-bacia mais urbanizada entre os afluentes ao lago. Já no braço do Ribeirão Bananal, por outro lado, a concentração é muito baixa ao longo de todo ano, provavelmente por consequência do bom grau de preservação desta sub-bacia, que está quase integralmente contida dentro do Parque Nacional de Brasília.

Outro ponto interessante é a temperatura e a sua relação com o lago ao longo das estações do ano. Na época do verão (entre dezembro e março), a temperatura média do ar é mais alta, 
aquecendo a superfície do lago e gerando uma diferença de temperatura entre as camadas superiores e profundas. Devido à diferença de densidade, essas águas não se misturam, causando assim a estratificação térmica. Em contraponto, nas épocas de inverno, entre junho e setembro, o ar fica mais frio causando um resfriamento da camada superior do reservatório e consequentemente uma mistura. Isso pode ser analisado na imagem abaixo:

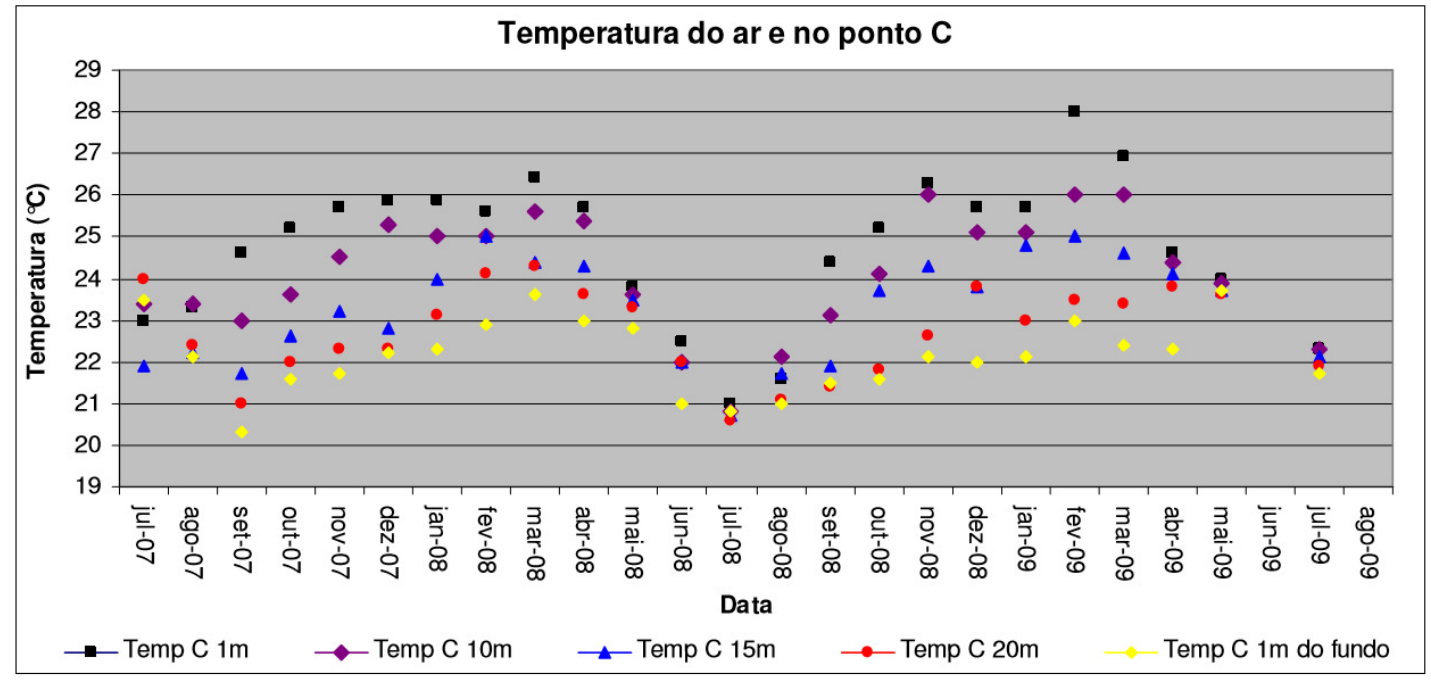

Figura 2. Temperatura do Lago nas diferentes profundidades (Liporoni, 2012).

Sendo assim, essa estratificação impede a água de circular de maneira homogênea, tendo duas camadas agindo de diferentes formas. A camada de cima então recebe mais oxigênio e tem uma melhor qualidade de água e oxigênio dissolvido (OD) em sua composição, enquanto que a camada de baixo, por não ter contato com a atmosfera, fica com pouco oxigênio dissolvido. Isso pode ser visto claramente no gráfico abaixo:

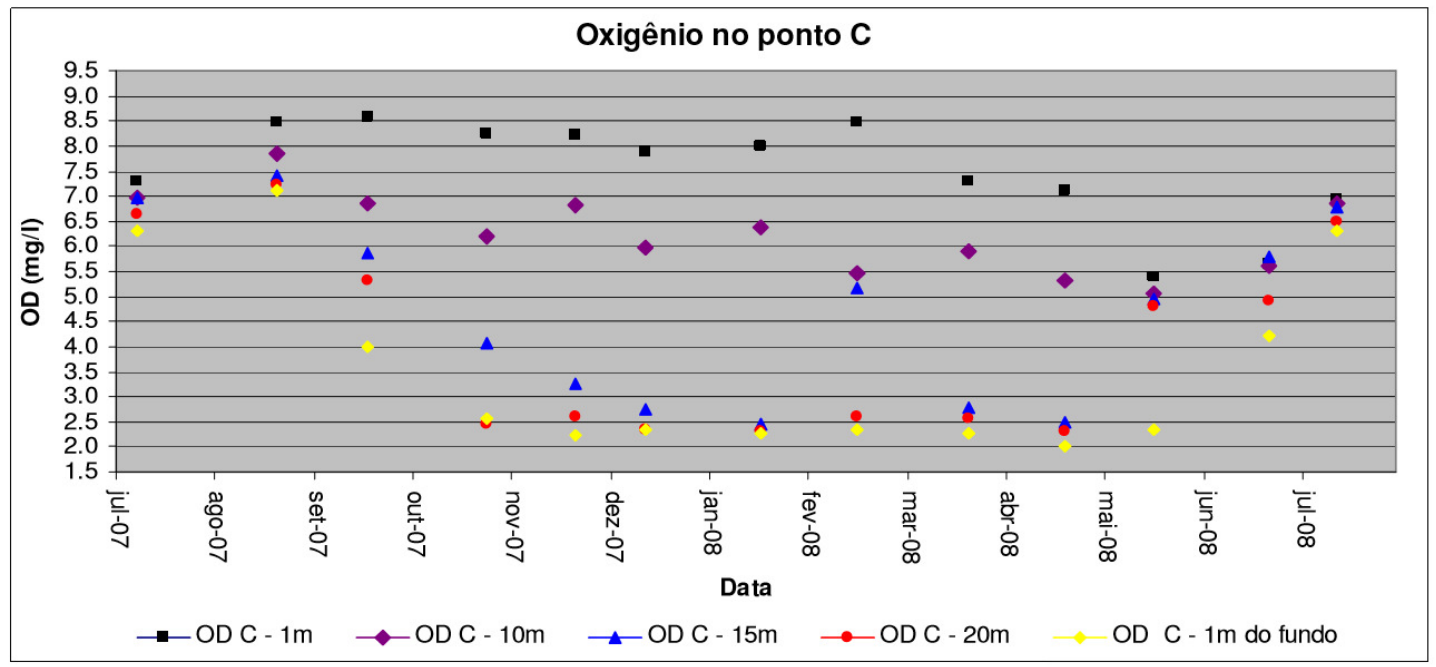

Figura 3. Oxigênio Dissolvido no lago de acordo com as épocas do ano (Liporoni, 2012). 
O fenômeno da estratificação tem implicações para a modelagem pretendida neste trabalho, devido ao caráter unidimensional desta.

\subsection{Modelagem de qualidade de água}

Muitos dos fenômenos naturais podem ser representados por meio de equações e expressões matemáticas. Essa é uma prática comum nas áreas de engenharia e de recursos hídricos e que vem evoluindo desde o início do século XX. Esse fato resulta da necessidade de entender, prever e mitigar problemas relacionados com o meio ambiente. A evolução dos equacionamentos cada vez mais complexos, contribuíram para o surgimento dos modelos ambientais, dentre eles os modelos de qualidade da água (Liporoni, 2012).

O monitoramento da qualidade de água é um procedimento relativamente custoso em termos de pessoal, tempo e recursos financeiros, fazendo com que não seja possível dispor de medições diárias ou em altas frequências temporais. Nesse contexto, os modelos de qualidade de água são usados para explorar e melhorar a disponibilidade de informações (Larentis, 2004).

Segundo Tschiedel (2013), um modelo de qualidade de água pode ser entendido como a consolidação, em um programa computacional, de conceitos e equações que regem, ou buscam explicar empiricamente, os fenômenos físicos de entrada, saída e transferência de poluentes em um corpo hídrico. Tal programa normalmente é dotado de um meio de interface com o usuário.

Com sua utilização é possível realizar projeções e prognósticos. Dessa forma, esse tipo de ferramenta é bastante útil para representações de cenários e alternativas. Esse fato decorre da necessidade de se preverem ou simularem problemas que vêm se tornando cada vez mais comuns em mananciais situados em bacias hidrográficas onde existe grande concentração populacional (Liporoni, 2012).

A maior parte dos modelos de qualidade de água se dedica a representar transporte e dinâmica dos poluentes nos cursos d'água. Diversos modelos foram propostos para esse fim, como o SISBAHIA (Rosman, 1989 e Rosman, 2000), o CE-Qual-W2 (ENVIRONMENTAL AND HYDRAULIC LABORATORIES, 1986), IPH-ECO (Fragoso Jr, 2007) e o HEC-RAS (USACE, 2010), sendo que este último vem sendo usado no projeto em pesquisa já mencionado. Nesses modelos, as cargas poluentes produzidas na bacia hidrográfica são condições de contorno à simulação do manancial. 
No caso de reservatórios, os modelos de transporte e dinâmica de qualidade de água podem ter diferentes graus de detalhamento espacial, podendo ser tri- bi- ou unidimensionais. Os modelos 1D, como o HEC-RAS, são relativamente simples, uma vez que só é possível obter um resultado médio da qualidade de água em cada seção transversal do rio ou reservatório. Entretanto, em reservatórios muito ramificados, é possível discretizar o sistema em vários braços, permitindo uma espacialização dos resultados de qualidade de água, sem incorrer em um custo computacional muito elevado. O modelo HEC-RAS, a ser usado neste trabalho, possui essa característica.

No âmbito do Lago Paranoá, cabe destacar alguns trabalhos importantes de simulação de qualidade de água, que serão importantes referências para o presente trabalho. Em primeiro lugar, deve-se mencionar o trabalho de Liporoni (2012), que aplicou preliminarmente o modelo bidimensional CE-QUAL-W2 ao lago Paranoá. Este trabalho também fez uma primeira avaliação do impacto das retiradas de água previstas na qualidade de água do lago.

\subsection{O modelo HEC-RAS}

\subsubsection{Aspectos gerais}

O modelo HEC-RAS (USACE, 2010) foi desenvolvido pelo corpo de engenheiros do exército dos EUA, inicialmente focado em estudos hidrodinâmicos de controle de cheias, em escala unidimensional. Posteriormente, foram agregadas ao modelo a possibilidade de simulação de sedimentos, e mais recentemente, a simulação de alguns parâmetros de qualidade de água, a saber: temperatura, nitrogênio dissolvido (nas formas de nitrato, nitrito, nitrogênio amoniacal e nitrogênio orgânico), fósforo dissolvido (nas formas de ortofosfato e fósforo orgânico), algas, DBO e oxigênio dissolvido.

Previamente à simulação de qualidade de água propriamente dita, é necessário o ajuste do modelo hidrodinâmico, de forma a determinar as velocidades do fluxo ao longo do reservatório. Isto porque o modelo de qualidade de água adota uma abordagem de advecçãodispersão. Ou seja, o poluente pode ser transportado tanto por advecção, devido ao fluxo da água, quanto por dispersão (diferenças de concentração). Além disso, a simulação do HECRAS é dividida primeiramente em simulação da temperatura, uma vez que esta influencia a dinâmica das reações de qualidade de água. Só então é possível simular as interações entre os diferentes nutrientes. 
Segundo Drake (2010), o modelo HEC-RAS é menos preciso do que outros modelos de qualidade de água em muitos aspectos, tais como a capacidade de levar em conta os efeitos da topografia e da vegetação ripária na simulação da temperatura da água. Por outro lado, salienta que a popularidade do HEC-RAS entre engenheiros de recursos hídricos, bem como seu caráter de acesso gratuito, fazem desse modelo uma interessante alternativa para a integração de modelos hidrológicos e de qualidade de água.

\subsubsection{Escoamento em regime não-permanente (hidrodinâmica)}

Para resolução da hidráulica do reservatório, o modelo adota um procedimento numérico para resolução das equações hidrodinâmicas (equações de Saint-Venant), que são a equação da continuidade e a equação dinâmica ou conservação de quantidade de movimento (unidimensionais).

$\frac{\partial Q}{\partial x}+\frac{\partial A}{\partial t}-q_{l}$ (equação da continuidade)

$\frac{\partial Q}{\partial t}+\frac{\partial Q V}{\partial x}+g A\left(\frac{\partial z}{\partial x}+S_{f}\right)=0$ (equação dinâmica ou da quantidade de movimento)

onde $Q$ é a vazão na seção $\left(\mathrm{m}^{3} / \mathrm{s}\right)$, A é a área da seção transversal $\left(\mathrm{m}^{2}\right)$, qı é a vazão específica lateral $\left(\mathrm{m}^{3} / \mathrm{s} / \mathrm{m}\right)$, V é a velocidade média do escoamento $(\mathrm{m} / \mathrm{s}), \mathrm{S}_{f}$ é a inclinação da linha d'água $(\mathrm{m} / \mathrm{m})$, e $\partial \mathrm{t}, \partial \mathrm{x}$ e $\partial \mathrm{z}$ são incrementos de tempo, comprimento longitudinal e profundidade, respectivamente.

A inclinação da linha d'água é calculada pela equação de Manning, ou seja:

$$
S_{f}=\frac{Q|Q| n^{2}}{2,208 \cdot R_{h}^{4 / 3} \cdot A^{2}}
$$

onde $R_{h}$ é o raio hidráulico $(m)$ e $n$ é o coeficiente de rugosidade de Manning.

As equações de Saint-Venant são resolvidas pelo HEC-RAS por meio de um procedimento numérico, usando quatro pontos no entorno do ponto cuja hidráulica deve ser resolvida. Este esquema implícito é conhecido como box scheme, e mais detalhes sobre seu equacionamento podem ser obtidos em USACE (2010).

Idealmente, um modelo hidrodinâmico como o HEC-RAS é calibrado, ou seja, ajustado às condições locais, por meio da variação de parâmetros, até que os níveis simulados pelo 
modelo reproduzam níveis observados em campo. O parâmetro principal para calibração é o coeficiente de Manning, que representa a resistência do canal ao escoamento.

\subsubsection{Simulação da qualidade de água - transporte}

O modelo HEC-RAS é unidimensional e simula o transporte e a dinâmica de parâmetros de qualidade de água. O transporte pode se dar por advecção (velocidade do escoamento) ou por difusão/dispersão (diferenças de concentração). Além disso, o modelo simula o decaimento e produção de parâmetros de qualidade por diversos processos: oxidação, sedimentação, respiração e fotossíntese algal, entre outros.

A equação diferencial que regula o transporte é a equação de advecção-difusão, mostrada abaixo.

$$
\begin{aligned}
V^{i+1} \cdot \emptyset^{i+1}= & V^{i} \cdot \emptyset^{i}+\Delta t \cdot\left[Q_{m} \cdot \emptyset_{m}^{*}-Q_{j} \cdot \emptyset_{j}^{*}+D_{j} \cdot A_{j} \cdot \frac{\partial \emptyset^{*}}{\partial x_{j}}-D_{m} \cdot A_{m} \cdot \frac{\partial \emptyset^{*}}{\partial x_{m}}\right] \pm \Delta t \\
& \cdot \frac{\partial \emptyset}{\partial x} S S
\end{aligned}
$$

onde $V^{i+1}$ e $V^{i}$ são, respectivamente, os volumes da célula no intervalo atual e anterior, em $\mathrm{m}^{3} ; \phi^{i+1}$ e $\phi^{i}$ são as concentrações médias do poluente ou da carga térmica na célula $\left(\mathrm{kg} \cdot \mathrm{m}^{-3}\right.$ ou ㅇ $\left.C . \mathrm{m}^{-3}\right) ; Q_{m}$ e $Q_{j}$ são as vazões nas faces de montante e jusante da célula $\left(\mathrm{m}^{3} \cdot \mathrm{s}^{-1}\right) ; \emptyset_{m}^{*}$ e $\emptyset_{j}^{*}$ são as concentrações calculadas nas faces de montante e jusante (kg. $\mathrm{m}^{-3}$ ou $\left.{ }^{\circ} \mathrm{C} \cdot \mathrm{m}^{-3}\right) ; D_{m}$ e $D_{j}$ são os coeficientes de dispersão nas faces de montante e de jusante $\left(\mathrm{m}^{2} \cdot \mathrm{s}^{-1}\right), A_{m}$ e $A_{j}$ são as

áreas da seção transversal nas faces de montante e jusante $\left(\mathrm{m}^{2}\right) ; \mathrm{e} \frac{\partial \emptyset}{\partial x} \mathrm{SS}$ é o balanço de energia

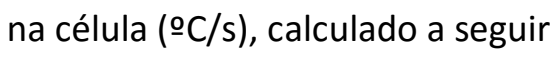

Os coeficientes de dispersão são calculados internamente pelo modelo a partir de variáveis hidráulicas.

Esta equação é usada pelo modelo tanto para simular o transporte de energia quanto de nutrientes.

3.3.4. Simulação de qualidade de água - balanço de energia

O cálculo da temperatura da água na célula é derivado de um balanço energético que determina se uma célula é uma "fonte" ou "sumidouro" de calor: 


$$
\frac{\partial \emptyset}{\partial x} S S=\frac{q_{l i q}}{\rho_{w} \cdot C_{p w}} \cdot \frac{A_{s}}{V}
$$

Onde qliq é o balanço energético na interface da célula com a atmosfera $\left(W / m^{2}\right), \rho_{w}$ é a massa específica da água $\left(\mathrm{kg} / \mathrm{m}^{3}\right), \mathrm{C}_{\mathrm{pw}}$ é o calor específico da água $\left(\mathrm{J} / \mathrm{kg} \cdot{ }^{\circ} \mathrm{C}\right)$, As é a área superficial da célula $\left(\mathrm{m}^{2}\right)$ e $V$ é o volume da célula $\left(\mathrm{m}^{3}\right)$

O balanço energético qliq leva em conta a radiação solar de onda curta, o balanço de radiação de onda longa e os fluxos de calor sensível e latente, conforme abaixo:

$\mathrm{q}_{\mathrm{liq}}=\mathrm{q}_{\mathrm{sw}}+\mathrm{q}_{\mathrm{atm}}-\mathrm{q}_{\mathrm{lw}}-\mathrm{q}_{\mathrm{s}}-\mathrm{q}_{\mathrm{I}}$

onde qliq é a energia líquida recebida pela célula a partir da superfície, em um dado intervalo de tempo, qsw é a radiação solar absorvida, qatm é a radiação de onda longa transferida da

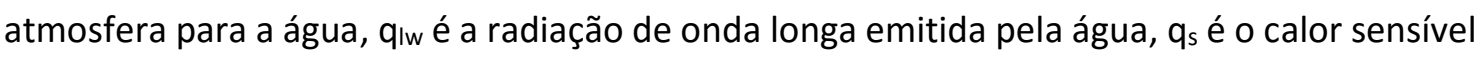
e qı o calor latente, todos em $\mathrm{W} / \mathrm{m}^{2}$.

A radiação solar absorvida é calculada a partir da radiação incidente, descontada a parcela refletida (albedo). A radiação incidente pode ser informada diretamente ou calculada internamente pelo modelo, a partir da latitude e altitude do local. $O$ albedo também é calculado pelo modelo, a partir da distância relativa da terra ao sol e da cobertura de nuvens. A radiação de onda longa é calculada a partir da equação de Stephan-Boltzmann, corrigida pelas emissividades da água e do ar.

Já os fluxos de calor sensível e latente são calculados a partir de aproximações do gradiente de temperatura e pressão de vapor, respectivamente, e levam em conta ainda a estabilidade atmosférica decorrente da ação do vento, conforme abaixo:

$q_{s}=\frac{K_{h}}{K_{w}} \cdot C_{p} \cdot \rho_{w} \cdot\left(T_{a}-T_{w}\right) \cdot f(U)$ fluxo de calor latente

$q_{l}=\frac{0,622}{P} \cdot L \cdot \rho_{w} \cdot\left(e_{s}-e_{a}\right) \cdot f(U)$ fluxo de calor latente

onde $\mathrm{Cp}$ é o calor específico da água $(\mathrm{J} / \mathrm{Kg} / \mathrm{o} \mathrm{C})$, $\rho_{\mathrm{w}}$ é a massa específica da água $\left(\mathrm{kg} / \mathrm{m}^{3}\right)$, L é o calor latente de vaporização $(\mathrm{J} / \mathrm{Kg}), \mathrm{T}_{\mathrm{a}}$ é a temperatura do $\mathrm{ar}, \mathrm{T}_{\mathrm{w}}$ é a temperatura da água $(\stackrel{\circ}{\mathrm{C}})$, $\mathrm{e}_{\mathrm{s}}$ é a pressão de saturação do vapor, $\mathrm{e}_{\mathrm{a}}$ é a pressão do vapor $(\mathrm{mb})$.

Já Kh/Kw é a razão de difusividade, um parâmetro que permite ao usuário dividir o fluxo entre calor latente e sensível, e f(U) é a função vento, explicada a seguir. Estes dois parâmetros são os únicos que dependem de julgamento do usuário, de forma que usados no HEC-RAS para calibrar o modelo de temperatura da água. 
A razão de difusividade tem valor recomendado entre 0,9 e 1,1. Já a função vento é dada por: $f(U)=R\left(a+b \cdot U^{c}\right)$,

onde $a, b$ e c são parâmetros definidos pelo usuário, $U$ é a velocidade do vento (em $\mathrm{m} / \mathrm{s}$ ), enquanto $R$ é uma função do número de Richardson, um adimensional que expressa o grau de estabilidade atmosférica. $O$ valor de $\mathrm{R}$ em geral é mantido na unidade.

Assim, os parâmetros a,b e c são os que mais influenciam a temperatura da água, pois um aumento no seu valor gera um aumento no fluxo de calor sensível, e principalmente um aumento no fluxo de calor latente (evaporação), diminuindo a temperatura da água. É por meio da variação desses parâmetros que se consegue um ajuste mais efetivo do modelo em termos de temperatura da água.

Para o balanço atmosférico de energia, portanto, o modelo requer ainda a informação de séries históricas dos seguintes dados meteorológicos: temperatura do ar, umidade relativa, pressão atmosférica, velocidade do vento e cobertura de nuvens, além da radiação incidente.

\subsubsection{Simulação da qualidade de água - dinâmica de nutrientes}

As variáveis de qualidade de água que podem ser modeladas pelo HEC-RAS são as seguintes - Nitrogênio dissolvido na forma de nitrito (NO2)

- Nitrogênio dissolvido na forma de nitrato (NO3)

- Nitrogênio dissolvido na forma orgânica (OrgN)

- Nitrogênio dissolvido na forma de amônio (NH4)

- Fósforo dissolvido na forma orgânica (OrgP)

- Fósforo dissolvido na forma inorgânica - ortofosfato (PO4)

- Algas (A)

- Demanda Bioquímica de Oxigênio - carbonácea (DBOc)

- oxigênio dissolvido (OD)

As interrelações entre essas variáveis são controladas por parâmetros ajustáveis pelo usuário, mostradas abaixo. 


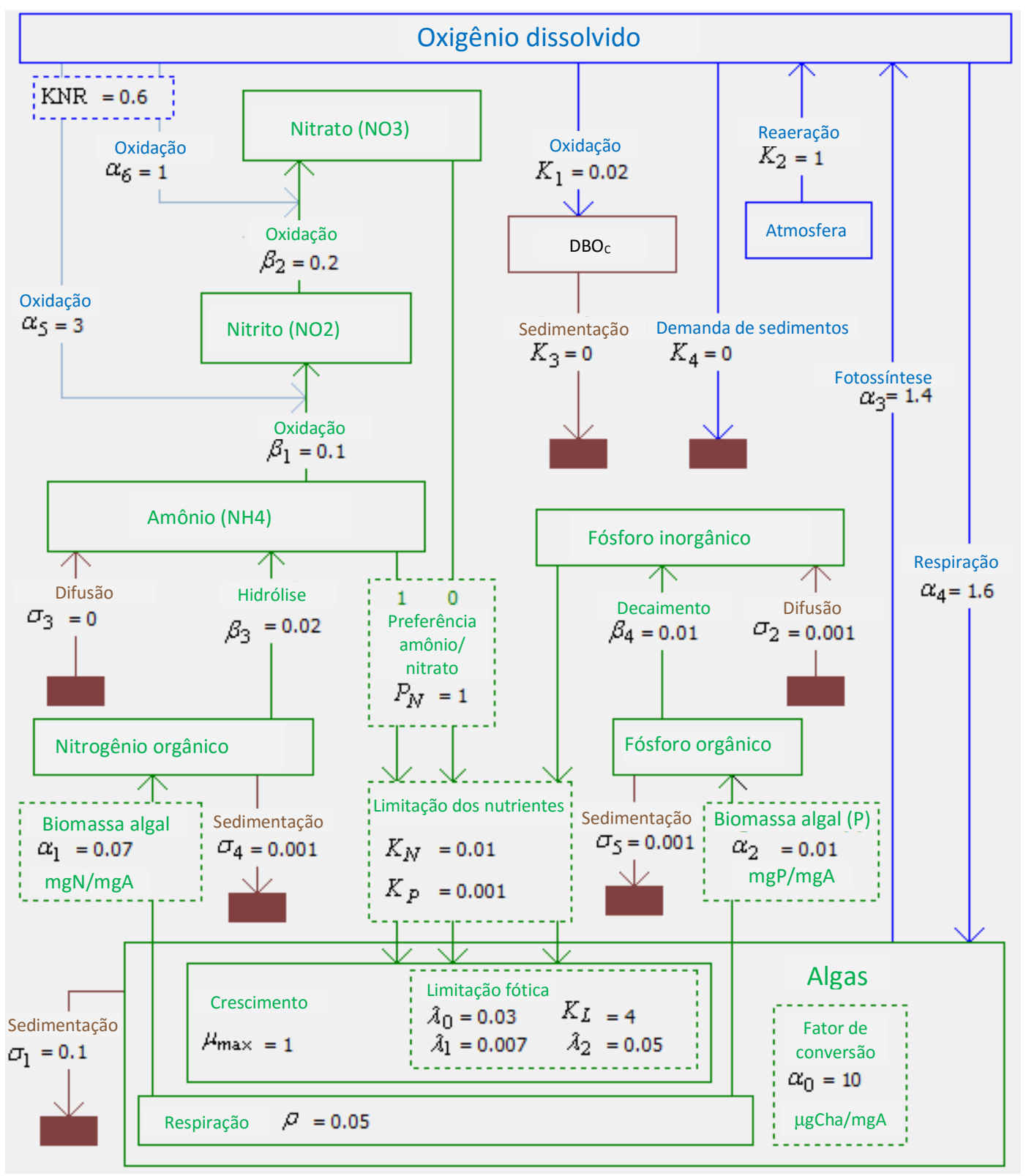

Figura 4. Fluxograma de interrelação entre nutrients no modelo HEC-RAS

Cada parâmetro do modelo possui uma faixa de variação sugerida pelo modelo (que pode ser visualizada passando-se o mouse sobre a variável). Definir valores fora dessa faixa é permitido na maior parte dos casos.

Os parâmetros relacionados com nutrientes incluem diversas taxas de reação entre algas, nitrogênio, fósforo, oxigênio, DBO e sedimentos. Essas taxas controlam a variação do termo $\frac{\partial \emptyset}{\partial x} S S$ (fontes/sumidouros) da equação de advecção-difusão. 


\section{Dependência da temperatura}

Algumas reações na água são fortemente influenciadas pela temperatura. Taxas de reação são especificadas para a temperatura de 20 으, sendo corrigidas pelo o modelo de acordo com a temperatura local. A relação entre taxa de reação e temperatura é modelada por meio da lei de Arrenius:

$$
k_{T}=k_{20} \cdot \theta^{(T-20)}
$$

onde $\mathrm{k}_{\mathrm{T}}$ é a taxa de reação à temperatura $\mathrm{T}, \mathrm{k}_{20}$ é a taxa de reação a 20 으 e $\theta$ é um coeficiente de correção térmico (normalmente 1,024 para reações físicas e 1,047 para reações químicas, com algumas exceções)

\subsubsection{Algas}

O modelo de qualidade de água considera somente algas fitoplantônicas flutuantes, que consomem nutrientes da coluna d'água (sem raízes). O crescimento e respiração algais afetam a concentração de algas (A), de nutrientes (NH4, NO3, PO4, OrgN e OrgP) e de oxigênio. A fotossíntese produz oxigênio, enquanto a respiração consome essa substância). Algas utilizam fósforo e nitrogênio nas formas inorgânicas (NH4, NO3 e PO4). Por outro lado, produzem as formas orgânicas de nitrogênio (OrgN) e fósforo (OrgP).

\section{Concentração de biomassa algal (A)}

A única fonte de biomassa algal (A) é o crescimento das algas. Por outro lado, são considerados dois sumidouros de algas: respiração e sedimentação. Assim, o balanço de concentração algal é o seguinte:

$$
\begin{aligned}
A_{F / S}=\quad & +A \mu \quad \text { (crescimento algal) } \\
& -A \rho \quad \text { (respiração algal) } \\
& -\sigma_{1} \cdot \mathrm{A} / \mathrm{d} \quad \text { (sedimentação algal) }
\end{aligned}
$$

Onde $\rho$ é a taxa de respiração $\left(\operatorname{dia}^{-1}\right)$ definida pelo usuário, $\sigma 1$ é a taxa de sedimentação ( $\mathrm{m} / \mathrm{dia})$, definida pelo usuário, d é a profundidade média da seção e $\mu$ é a taxa de crescimento algal (os três processos são dependentes da temperatura).

A taxa de crescimento $m$ depende de funções de limitação de nutrientes, conforme abaixo: $\mu=\mu_{\max } \cdot G L$ 
Onde $\mu_{\max }$ é a máxima taxa de crescimento (definida pelo usuário) e GL é o limitante de crescimento, função da disponibilidade de nitrogênio (FN), fósforo (FP) e luz (FL).

GL=FL.FP.FN

O fator de limitação por nitrogênio (FN) é função da constante de Michaelis-Menton para nitrogênio (KN), informada pelo usuário, bem como das concentrações de amônia (NH4) e nitrato (NO3).

O fator de limitação para nitrogênio é dado por

$$
F N=\frac{\mathrm{NH}_{4}+\mathrm{NO}_{3}}{\mathrm{NH}_{4}+\mathrm{NO}_{3}+\mathrm{KN}}
$$

A constante de Michaelis-Menton determina a eficiência com a qual as algas retiram nitrogênio e fósforo a baixas concentrações. Quanto maior seu valor, menor será o fator de limitação de nitrogênio e consequentemente menor a taxa de crescimento algal.

O fator de limitação para fósforo (FP) é função da constante de Michaelis-Menton para fósforo (KP), definida pelo usuário, bem como da concentração de fósforo inorgânico.

O fator de limitação é dado por:

$$
F P=\frac{P O_{4}}{P O_{4}+K P}
$$

Já o fator de limitação fótico (FL) resulta de uma integração ao longo da profundidade da seção:

$$
F L=\frac{1}{\lambda \cdot d} \ln \left(\frac{K L+I_{0}}{K L+I_{0} \cdot e^{-\lambda d}}\right)
$$

Onde $I_{0}$ é a intensidade fótica na superfície $\left(W / \mathrm{m}^{2}\right)$, d é a profundidade média da seção $(\mathrm{m})$, $\lambda$ é o coeficiente de extinção da luz na água $\left(\mathrm{m}^{-1}\right)$ e $K L$ é o fator de saturação da luz, definido pelo usuário.

Praticamente toda a radiação proveniente da atmosfera (exceto radiação visível) é absorvida no primeiro metro abaixo da superfície, de forma que a intensidade fótica (Io) aplicada a modelos de qualidade de água geralmente é estimada como uma fração do balanço de energia. No HEC-RAS, a intensidade fótica é dada por $\mathrm{I}_{0}=\mathrm{a}_{\mathrm{sw}} \cdot \mathrm{q}_{\mathrm{sw}}$ onde $\mathrm{a}_{\mathrm{sw}}$ é um coeficiente de atenuação, atualmente fixado pelo HEC-RAS em 0,5. Já o coeficiente de extinção da luz na água $(\lambda)$ é calculado por: $\lambda=\lambda_{0}+\lambda_{1} \cdot \alpha_{0} \cdot A+\lambda_{2} \cdot\left(\alpha_{0} \cdot A\right)^{2 / 3}$ 
Onde $\lambda_{0}$ é a parcela do coeficiente não devida a algas, $\lambda_{1}$ é a parcela linear devida ao sombreamento pelas algas, e $\lambda_{2}$ é a parcela não-linear do coeficiente devida ao sombreamento pelas algas, e $\alpha_{0}$ é a razão entre clorofila-a e biomassa algal ( $\mu \mathrm{g} \mathrm{Chl}-\mathrm{a} / \mathrm{mg} \mathrm{A}$ ), todos definidos pelo usuário

\subsubsection{Nitrogênio}

O nitrogênio é uma substância de particular interesse, uma vez que concentrações elevadas têm efeitos na saúde de seres humanos e animais. Nitrogênio orgânico e nitrito são formas pouco estáveis em águas bem oxigenadas, de forma que concentrações elevadas desses parâmetros indicam lançamento de esgotos nas proximidades. Nitrato e amônio, por serem mais estáveis, normalmente são indicadores de lançamentos de esgotos mais distantes. Concentrações de amônio estão mais associadas a esgoto doméstico, enquanto concentrações de nitrato normalmente estão ligadas a poluição difusa, principalmente de áreas agrícolas.

O ciclo do nitrogênio na água, em condições aeróbias, obedece a uma transformação constante do nitrogênio orgânico (OrgN) em amônio (NH4), desta para nitrito (NO2) e finalmente para nitrato (NO3).

A forma simulada do nitrogênio amoniacal é o amônio $\mathrm{NH} 4$, visto que a amônia $\left(\mathrm{NH}_{3}\right)$ só é relevante em pHs elevados, acima do comumente encontrado em rios e lagos.

Além do ciclo mencionado acima, que ocorre de forma relativamente permanente, o ciclo de vida das algas também consome e produz nitrogênio. Por fim, a sedimentação representa um sumidouro potencial para a substância.

\section{Fontes/sumidouros de nitrogênio orgânico (OrgN)}

A única fonte interna de nitrogênio orgânico é a respiração algal. Os sumidouros, por outro lado, incluem a sedimentação e hidrólise para formar amônio (NH4).

$$
\begin{array}{lll}
\operatorname{OrgN}_{\mathrm{F} / \mathrm{S}}= & +\alpha_{1} \cdot \rho \cdot \mathrm{A} & \text { (respiração algal) } \\
& -\beta_{3} \cdot \operatorname{OrgN} & (\text { hidrólise OrgN } \rightarrow \mathrm{NH} 4) \\
& -\sigma_{4} \cdot \operatorname{OrgN} & (\text { sedimentação) }
\end{array}
$$


onde $\alpha 1$ é a fração de nitrogênio na biomassa algal (adimensional, definida pelo usuário), $\beta_{3}$ é a taxa de hidrólise (conversão em amônio) e $\sigma_{4}$ é a taxa de sedimentação (ambas em em $\left.\operatorname{dia}^{-1}\right)$

\section{Fontes/sumidouros de amônio (NH4)}

As fontes internas de amônio são a hidrólise a partir do nitrogênio orgânico, bem como absorção a partir da zona bentônica. Já os sumidouros incluem a oxidação do amônio a nitrito (NO2) e consumo algal. Em síntese:

$$
\begin{aligned}
& \mathrm{NH}_{\mathrm{F} / \mathrm{S}}=\quad+\beta_{3} \cdot \operatorname{OrgN} \quad \text { (hidrólise OrgN } \rightarrow \mathrm{NH} 4 \text { ) } \\
& +\sigma_{3} / \mathrm{d} \quad \text { (difusão a partir do benthos) } \\
& -\beta_{1} \cdot\left(1-e^{-K N R . D O X}\right) \cdot N H 4 \quad \text { (oxidação } \mathrm{NH} 4 \rightarrow \mathrm{NO} 2 \text { ) } \\
& -\mathrm{F}_{1} \cdot \alpha_{1} \cdot \mu \mathrm{A} \quad \text { (consumo algal) }
\end{aligned}
$$

Onde $\beta_{1}$ é a taxa de reação (oxidação) de amônio a nitrito $\left(\operatorname{dia}^{-1}\right), \sigma_{3}$ é a taxa de difusão do benthos $\left(\mathrm{mg} / \mathrm{m}^{2} / \mathrm{dia}\right)$, KNR é um coeficiente de inibição de nitrificação de 1 a ordem $(1 / \mathrm{mg})$, todos definidos pelo usuário, e $F_{1}$ é a fração de consumo algal a partir do amônio (adimensional). Dox é a concentração de oxigênio. ( $\mathrm{mg} / \mathrm{l}$ )

A fração de consumo a partir do amônio $F_{1}$ é função do fator de preferência de nitrogênio (PN), bem como das concentrações de amônio e nitrato:

$$
F_{1}=\frac{P_{N} \cdot N H 4}{P_{N} \cdot N H 4+\left(1-P_{N}\right) \cdot N O 3}
$$

O fator de preferência de nitrogênio (PN) varia entre zero (situação em que a preferência algal é pelo nitrato) e um (situação em que a preferência algal é pelo amônio), sendo este último o valor normalmente adotado.

\section{Fontes/sumidouros de nitrito (NO2)}

A única fonte interna de nitrito é a oxidação a partir do amônio, e o único sumidouro é a oxidação a nitrato (NO3). Em síntese:

$$
\begin{array}{rlr}
\mathrm{NO}_{\mathrm{F} / \mathrm{S}}= & +\beta_{1} \cdot\left(1-\mathrm{e}^{-\mathrm{KNR} . \mathrm{OD}}\right) \cdot \mathrm{NH} 4 & \text { (oxidação } \mathrm{NH} 4 \rightarrow \mathrm{NO} 2) \\
& -\beta_{2} \cdot\left(1-\mathrm{e}^{-\mathrm{KNR} . \mathrm{OD}}\right) \cdot \mathrm{NO} 2 & \text { (oxidação } \mathrm{NO} 2 \rightarrow \mathrm{NO} 3)
\end{array}
$$


onde $\beta 2$ é a taxa de reação (oxidação) de nitrito a nitrato $\left(\right.$ dia $\left.^{-1}\right)$, definida pelo usuário, e OD é a concentração de oxigênio $(\mathrm{mg} / \mathrm{l})$

\section{Fontes/sumidouros de nitrato (NO3)}

A única fonte interna de nitrato é a oxidação do nitrito (NO2). O único sumidouro é a absorção das algas. Em síntese:

$$
\begin{aligned}
\mathrm{NO}_{\mathrm{F} / \mathrm{S}}= & +\beta_{2} \cdot\left(1-\mathrm{e}^{-\mathrm{KNR} \cdot \mathrm{OD}}\right) \cdot \mathrm{NO} 2 & & \text { (oxidação NO2 } \rightarrow \mathrm{NO} \text { ) } \\
& -\left(1-\mathrm{F}_{1}\right) \cdot \alpha_{1} \cdot \mu \mathrm{A} & & \text { (consumo algal) }
\end{aligned}
$$

Como visto, o consumo de nitrato pelas algas vai depender do fator de preferência do nitrogênio, já mencionado anteriormente.

\subsubsection{Fósforo}

O fósforo pode ocorrer naturalmente na água, devido à dissolução de rochas e minerais. A erosão do solo em áreas agrícolas é uma fonte antrópica importante. O fósforo aflui aos corpos d'água principalmente na forma particulada, que não é simulada no HEC-RAS. Esse desenvolvimento está sendo planejado em versões futuras (HEC, 2015).

Resíduos do metabolismo animal são uma outra fonte de fósforo, estando presente em esgotos principalmente na forma inorgânica (PO4). As fontes e sumidouros do fósforo, bem como os parâmetros que controlam sua cinética, são descritos em detalhes a seguir.

\section{Fontes/sumidouros de fósforo orgânico (OrgP)}

A única fonte interna de fósforo orgânico é a respiração das algas. Já os sumidouros são a decomposição em ortofosfato (PO4) e a sedimentação. Em síntese:

$$
\begin{aligned}
& \operatorname{Org} \mathrm{P}_{\mathrm{F} / \mathrm{S}}=\quad+\alpha_{2} \cdot \rho \cdot \mathrm{A} \quad \text { (respiração algal) } \\
& \left.-\beta_{4} \cdot \operatorname{OrgP} \quad \text { (decomposição OrgP } \rightarrow P O 4\right) \\
& \text { - } \sigma_{5} \text {. OrgP (sedimentação) }
\end{aligned}
$$

Onde b4 é a taxa de reação de fósforo orgânico a ortofosfato (dia ${ }^{-1}$ ), $\sigma 5$ é a taxa de sedimentação do fósforo orgânico $\left(\mathrm{dia}^{-1}\right)$ e $\alpha 2$ é a fração de fósforo na biomassa algal (adimensional), todas definidas pelo usuário. 


\section{Fontes/sumidouros de fósforo inorgânico (PO4)}

Existem duas fontes internas de ortofosfato: a decomposição do fósforo orgânico (OrgP) e a difusão a partir da zona bentônica. O único sumidouro de ortofosfato é o consumo algal. Em síntese:

$\begin{array}{llr}\mathrm{PO}_{\mathrm{F} / \mathrm{s}}= & +\beta_{4} \cdot \operatorname{OrgP} & \\ +\sigma_{2} / \mathrm{d} & & \text { (difusão da zona bentônica) } \\ -\alpha_{2} \cdot \mu \cdot \mathrm{A} & & \text { (consumo algal) }\end{array}$

Onde $\sigma_{2}$ é a taxa de difusão da zona bentônica para ortofosfato $\left(\mathrm{mg} / \mathrm{m}^{2} / \mathrm{dia}\right)$, definido pelo usuário.

\subsubsection{Demanda biológica de Oxigênio - carbonácea $\left(\mathrm{DBO}_{\mathrm{c}}\right)$}

O HEC-RAS contempla uma modelagem das reações de 1a ordem que descrevem a oxidação da DBO. O ciclo do carbono não é modelado nessa versão. Os sumidouros de DBO incluem a sedimentação e a decomposição (oxidação).

$\mathrm{DBO}_{\mathrm{F} / \mathrm{S}}=\quad-\mathrm{K}_{1} \cdot \mathrm{DBOc} \quad$ (oxidação)

$-K_{3} \cdot$ DBOc (sedimentação)

Onde $K_{1}$ é uma taxa de desoxigenação $\left(\right.$ dia $\left.^{-1}\right)$ e $K_{3}$ é a taxa de sedimentação da DBO (dia-1), ambas definidas pelo usuário.

\subsubsection{Oxigênio dissolvido - OD}

As fontes de oxigênio dissolvido são a fotossíntese algal e a reaeração a partir da atmosfera. Já os sumidouros incluem: respiração algal, oxidação dos sedimentos, decomposição da DBO e oxidação de amônio e nitrito. Em síntese:

$$
\begin{aligned}
\mathrm{OD}_{\mathrm{F} / \mathrm{S}=}= & +\mathrm{K}_{2} \cdot\left(\mathrm{OD} \mathrm{sat}_{\mathrm{s}} \mathrm{OD}\right) & & \text { (reaeração) } \\
& +\mathrm{A} \cdot\left(\alpha_{3} \cdot \mu-\alpha_{4} \cdot \rho\right) & & \text { (fotossíntese e respiração) } \\
& -\mathrm{K}_{1} \cdot \mathrm{DBOc} & & \text { (decomposição da DBO) } \\
& -\mathrm{K}_{4} / \mathrm{d} & & \text { (oxidação dos sedimentos) } \\
& -\alpha_{5} \cdot \beta_{1} \cdot \mathrm{NH}_{4} & & \text { (oxidação do amônio) } \\
& -\alpha_{6} \cdot \beta_{2} \cdot \mathrm{NO}_{2} & & \text { (oxidação do nitrito) }
\end{aligned}
$$


Onde $\mathrm{O}_{\text {sat }}$ é a concentração de oxigênio na condição de saturação $(\mathrm{mg} / \mathrm{l})$, calculada a partir da temperatura da água, $\alpha_{3}$ é a taxa de produção de oxigênio pelas algas (mgOD/mgA), $\alpha_{4}$ é a taxa de consumo de oxigênio pelas algas ( $\mathrm{mgOD} / \mathrm{mgA}), \alpha_{5}$ é a taxa de consumo de oxigênio pelo amônio (mgOD/mgN), $\alpha_{6}$ é a taxa de consumo de oxigênio pelo nitrito ( $\left.\mathrm{mgOD} / \mathrm{mgN}\right), \mathrm{K}_{2}$ é a taxa de reaeração $\left(\operatorname{dia}^{-1}\right)$ e $\mathrm{K}_{4}$ é a taxa de demanda dos sedimentos $\left(\mathrm{dia}^{-1}\right)$, todos definidos pelo usuário.

\section{Metodologia}

\subsection{Modelo utilizado e premissas}

O modelo de simulação de qualidade de água a ser usado é o HEC-RAS (USACE, 2010), desenvolvido pelo corpo de engenheiros do exército americano. Trata-se de um modelo unidimensional, ou seja, gera resultados médios para uma dada seção transversal do corpo hídrico. Não há, portanto, diferenciação da qualidade de água de uma margem para outra, na mesma seção, nem tampouco em diferentes profundidades de uma mesma seção. Este fator é certamente um limitante no caso do Lago Paranoá, uma vez que, conforme já apontado por Liporoni (2012), este reservatório apresenta estratificação térmica e de oxigênio durante os meses de verão. Tal estratificação, portanto, não será representada devido à escolha do modelo de simulação.

O ajuste do modelo de qualidade de água é feito em duas etapas. Num primeiro momento, trata-se de simular somente a hidrodinâmica do lago Paranoá, considerando as afluências nos diferentes braços (condições de contorno de montante) e os níveis operativos na barragem (condições de contorno de jusante). Feito isso, é possível simular o modelo de qualidade de água propriamente dito, a partir de estimativas de aportes de poluentes nos diversos braços e também nas estações de tratamento de esgoto.

A vazão afluente nas ETEs foi representada no modelo como um aporte lateral (lateral inflow), ou seja, uma condição de contorno adicional.

Não é possível calibrar o modelo hidrodinâmico em termos dos coeficientes de rugosidade de Manning, uma vez que não foi possível obter dados de nível d'água ao longo do reservatório, que seriam necessários para tal calibração. Assim, foram arbitrados coeficientes obtidos de literatura, no valor de $\mathrm{n}=0,035 \mathrm{~s} . \mathrm{m}^{-1 / 3}$, conforme Chow (1953). 
Embora essa escolha arbitrária do coeficiente de rugosidade possa ter efeito nos resultados do modelo de qualidade de água, simulações preliminares (não documentadas nesse relatório) mostraram que as velocidades de escoamento no lago Paranoá são extremamente baixas, devido ao alto tempo de residência do reservatório. Assim, a perda de carga é praticamente nula, fazendo com que a incerteza do coeficiente de Manning não tenha um papel expressivo. Em outras palavras, na prática o lago Paranoá não tem efeito de remanso significativo.

O intervalo de tempo de simulação é o intervalo diário, uma vez que é nesse intervalo que se possuem dados de vazão afluente e nível d'água. Internamente, no entanto, o modelo simula com intervalos menores, de forma a evitar instabilidades numéricas na resolução das equações hidrodinâmicas e de qualidade de água.

\subsection{Geometria}

A primeira etapa da construção do modelo foi conseguir a Batimetria do lago Paranoá com à Companhia de Saneamento Ambiental do Distrito Federal -CAESB. Esta Batimetria foi realizada pela CONCREMAT Engenharia em 2003 e os dados foram obtidos por meio da Escola Corporativa da CAESB. Os dados encontravam-se em formato $(X, Y, Z)$ ou UTM E, UTM N e cota do fundo.

A partir do conjunto de pontos tabulares, foi gerado um modelo de elevação tridimensional em ambiente de geoprocessamento. Os pontos batimétricos foram mesclados a dados do modelo de elevação digital SRTM (Shuttle Radar Topographic Mission) da NASA, para uma melhor configuração das margens. A partir desse conjunto de dados foi gerado uma rede de triângulos irregulares (Triangulated Irregular Newtork ou TIN). 


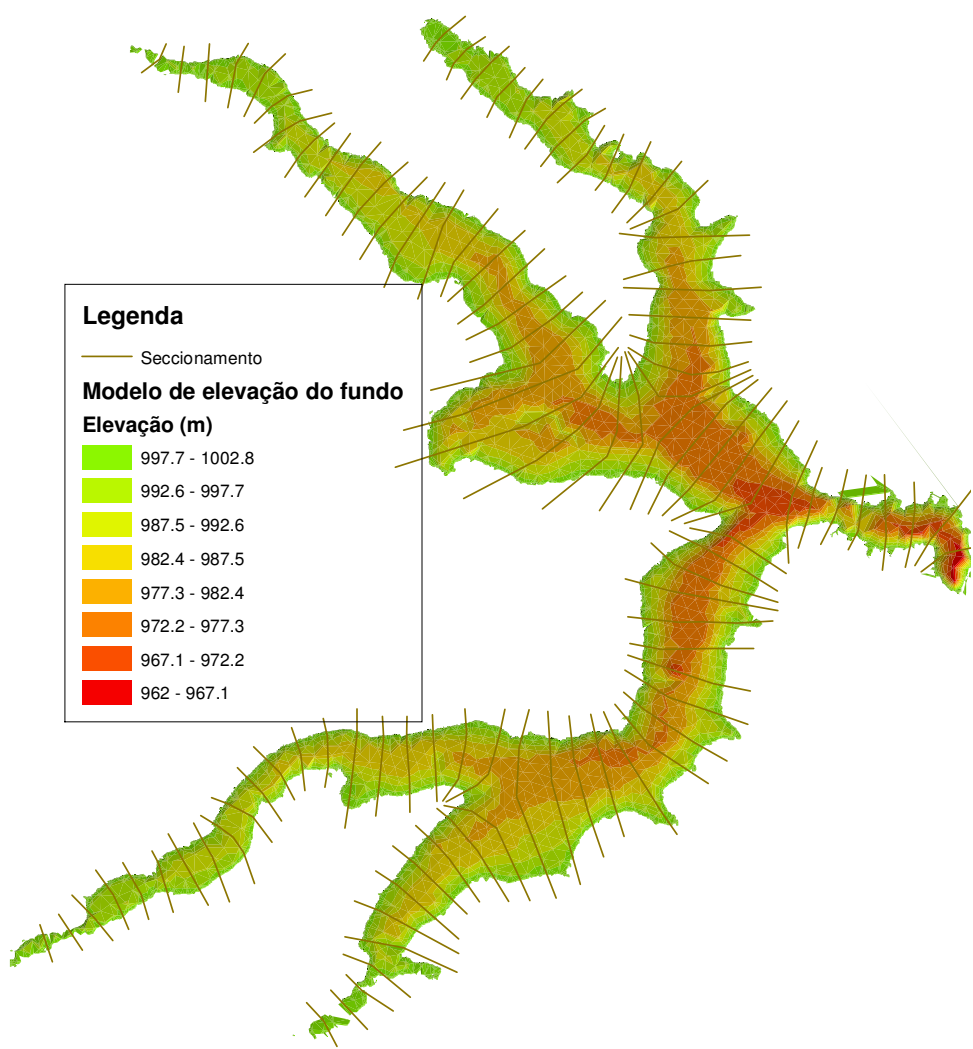

Figura 5. Modelo de elevação do fundo do lago Paranoá e traçado das seções transversais

Para inserção da geometria no HEC-RAS, foi necessário seccionar a geometria do fundo em vários pontos. Para isso, utilizou-se uma outra extensão no ArcGIS chamada Arc GEORAS, que lê o TIN gerado e exportar a geometria na forma de seções transversais. Foram geradas seções ao decorrer de todo o lago, com espaçamento de $500 \mathrm{~m}$ entre si.

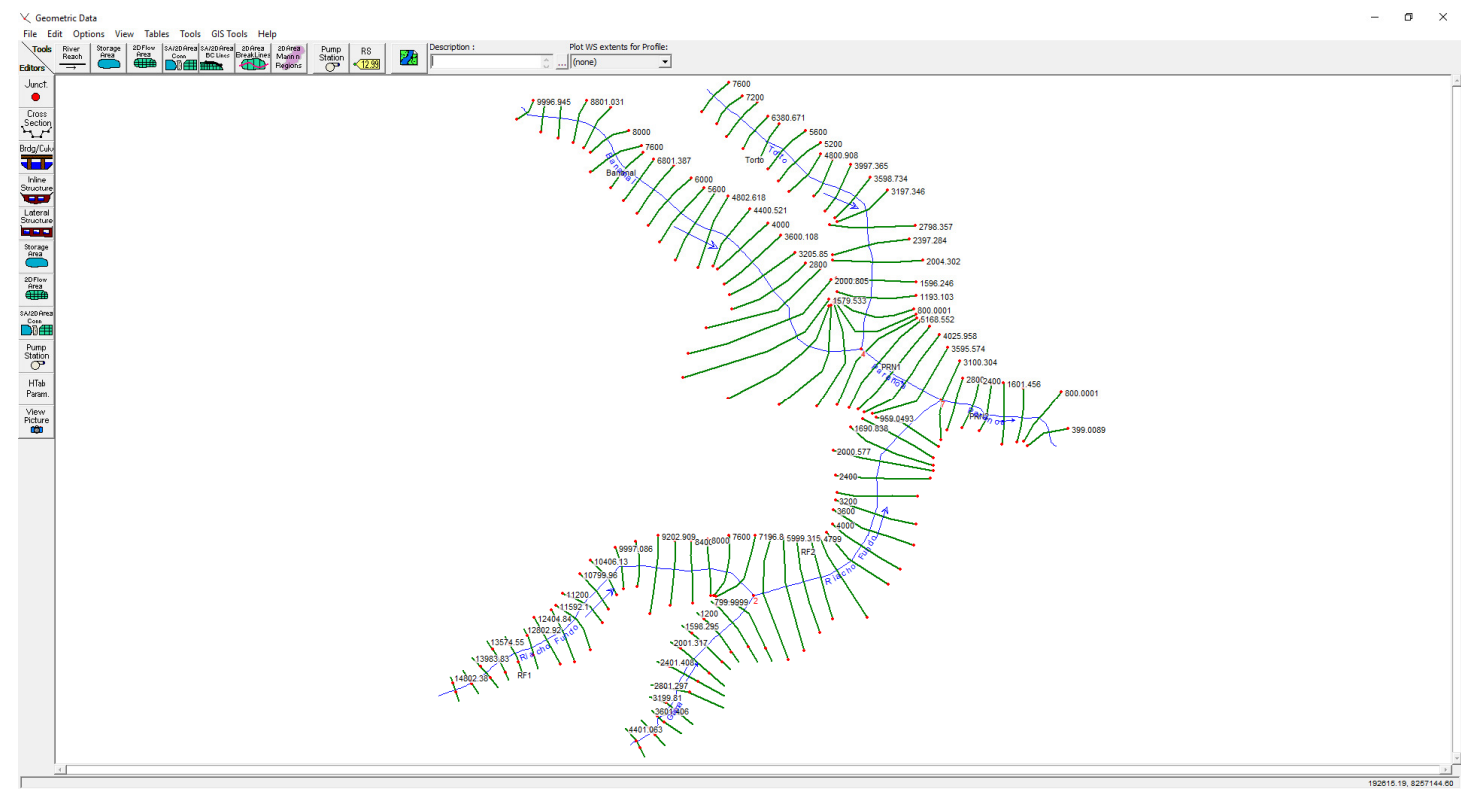

Figura 6. Topologia do lago Paranoá no modelo HEC-RAS 


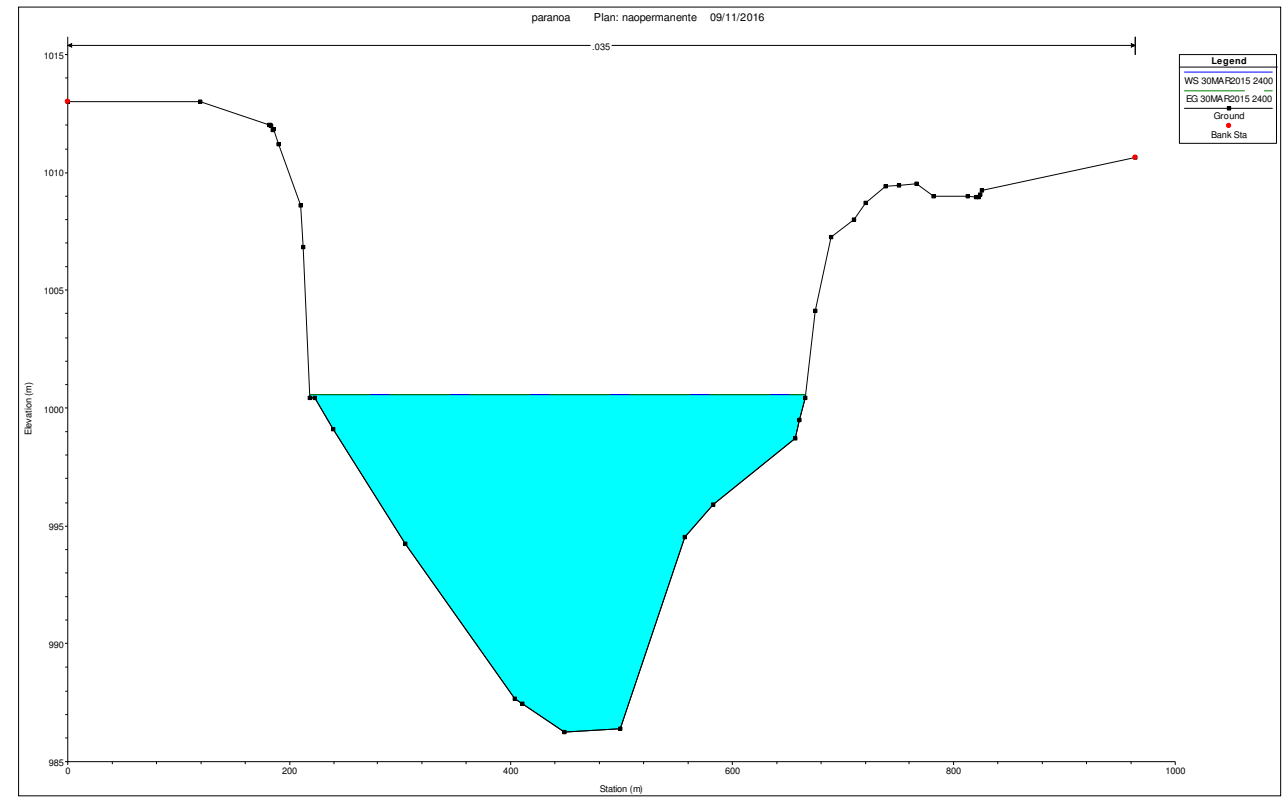

Figura 7. Seção transversal obtida a partir da batimetria do Lago Paranoá, para entrada no modelo HEC-RAS

\subsection{Dados de entrada}

\subsubsection{Vazões nos tributários}

A CAESB monitora vazões diariamente nos principais tributários do Lago Paranoá. Estes dados são importantes pois vão controlar a afluência em cada braço e consequentemente a hidrodinâmica do modelo.

A Figura 8 mostra uma síntese das estações fluviométricas utilizadas. 


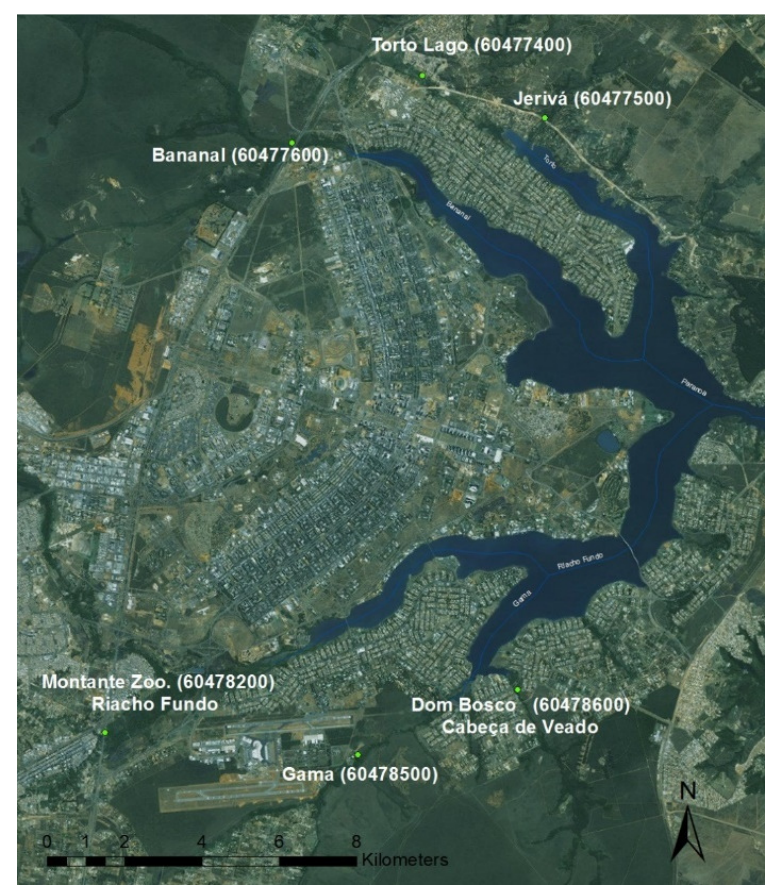

Figura 8. Localização das estações fluviométricas utilizadas

A estação Jerivá encontra-se no Córrego do Jerivá, que possui uma bacia bastante pequena, portanto com aportes pouco expressivos. Além disso, a extensão da série de dados é curta, de forma que esses dados foram desconsiderados.

Tabela 1. Estações fluviométricas utilizadas no estudo

\begin{tabular}{|l|l|l|l|}
\hline Nome & Código & Coordenadas & Área de drenagem \\
\hline Torto Lago & 60477400 & $\begin{array}{l}15^{\circ} 42^{\prime} 43^{\prime \prime} \mathrm{S} \\
47^{\circ} 52^{\prime} 42^{\prime \prime} \mathrm{W}\end{array}$ & $234,36 \mathrm{~km}^{2}$ \\
\hline Bananal - EPIA 003 & 60477600 & $\begin{array}{l}15^{\circ} 43^{\prime} 38^{\prime \prime} \mathrm{S} \\
47^{\circ} 54^{\prime} 36^{\prime \prime} \mathrm{W}\end{array}$ & $120,32 \mathrm{~km}^{2}$ \\
\hline Montante Zoológico & 60478200 & $\begin{array}{l}15^{\circ} 51^{\prime} 52^{\prime \prime} \mathrm{S} \\
47^{\circ} 57^{\prime} 25^{\prime \prime} \mathrm{W}\end{array}$ & $171,26 \mathrm{~km}^{2}$ \\
\hline Gama - Base aérea & 60478500 & $\begin{array}{l}15^{\circ} 52^{\prime} 14^{\prime \prime} \mathrm{S} \\
47^{\circ} 53^{\prime} 46^{\prime \prime} \mathrm{W}\end{array}$ & $134,93 \mathrm{~km}^{2}$ \\
\hline $\begin{array}{l}15^{\circ} 51^{\prime} 21^{\prime \prime} \mathrm{S} \\
47^{\circ} 51^{\prime} 26^{\prime \prime} \mathrm{W}\end{array}$ & $32,15 \mathrm{~km}^{2}$ \\
\hline $\begin{array}{l}\text { Dom Bosco - cabeça de } \\
\text { Veado }\end{array}$ & 60478600 & & \\
\hline
\end{tabular}

Já os dados das estações Dom Bosco-Cabeça de Veado e Gama foram somados, de forma a estimar a afluência a esse braço do Lago Paranoá.

Na estação Montante Zoológico, no Riacho Fundo, a série de dados possui falha no período de julho de 2004 a novembro de 2005. Para permitir a simulação neste período no HEC-RAS, a vazão no riacho Fundo foi estimada por meio de uma correlação entre a vazão neste ribeirão 
e a soma das vazões diárias nos córregos Gama e Cabeça de Veado, obtida no período comum de dados.

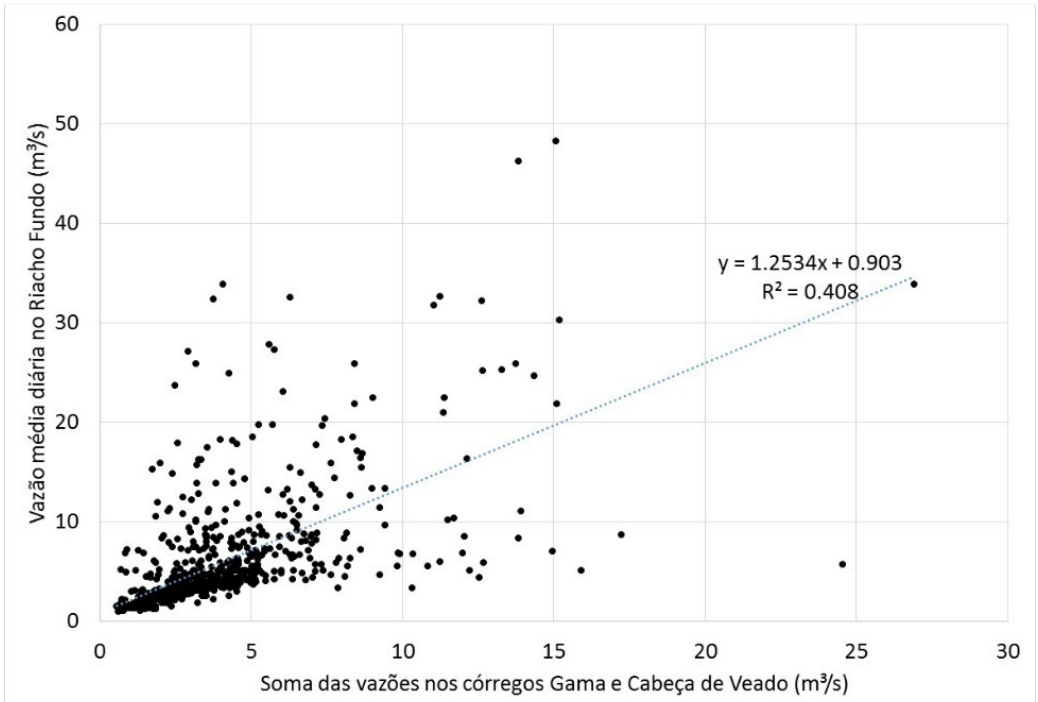

Figura 9. Correlação entre vazões diárias no Riacho Fundo e nos Córregos Gama e Cabeça de Veado, usada para preencher as falhas de medição no Riacho Fundo

Considera-se que este preenchimento não deve afetar significativamente os resultados do modelo de qualidade de água, por estar limitado ao primeiro ano da simulação, período em que o modelo ainda encontra-se na fase denominada de aquecimento.

\subsubsection{Nível d'água do lago}

Os níveis d'água do Lago são controlados pela operação da PCH Paranoá, operada pela CEB. Dependendo da afluência nos tributários, da necessidade de turbinamento para geração de energia e do risco de cheia, a CEB deflui uma quantidade maior ou menor de água. No período de seca, normalmente os níveis d'água se reduzem, devido à baixa afluência, alta evaporação e turbinamento ocasional. Já no período de chuvas, é comum a necessidade de abertura das comportas dos vertedores para diminuir o nível d'água do Lago, por questão de segurança. Além disso, em determinadas épocas do ano é desejável que determinados níveis d'água sejam mantidos para a realização de esportes aquáticos e usos de recreação.

Atualmente, a ADASA determina um nível mínimo que deve ser mantido mês a mês para compatibilização dos usos múltiplos, conforme Figura 5. 


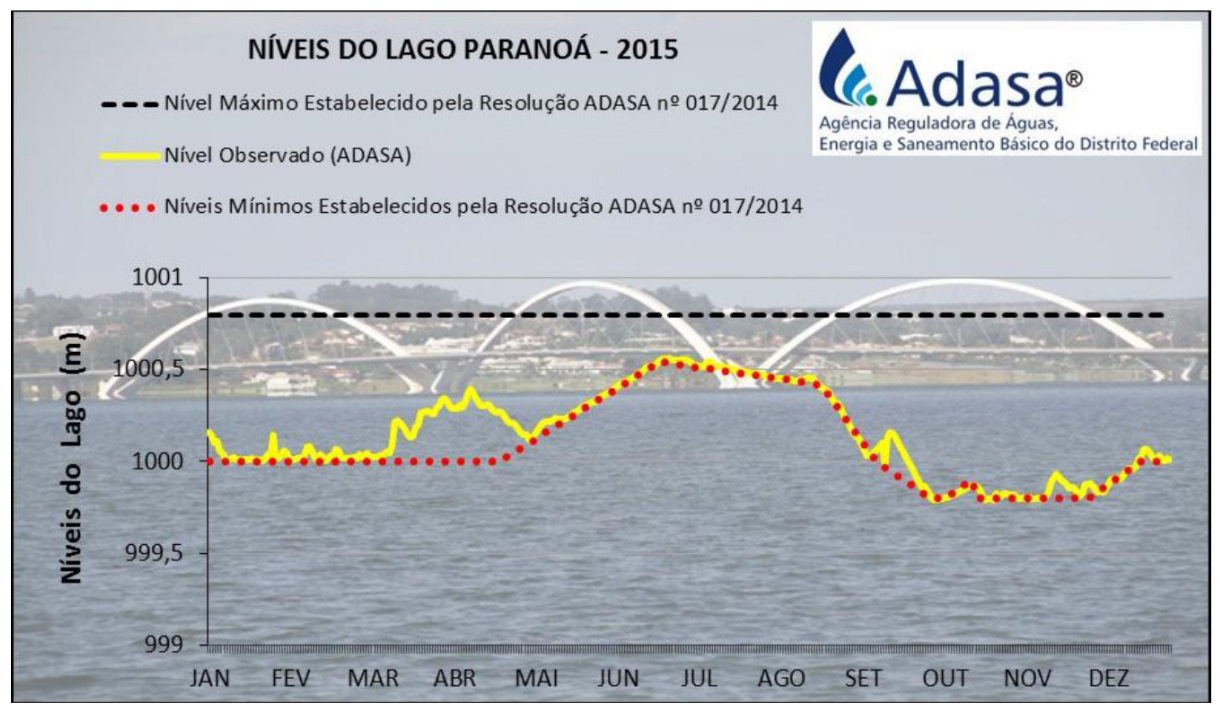

Figura 10. Níveis mínimos determinados pela ADASA para o Lago Paranoá

Os níveis operacionais também afetam a hidrodinâmica (velocidade da água) e consequentemente a qualidade de água do lago. Níveis mais baixos levam a um aumento de velocidade, menor tempo de detenção e aumento do transporte por advecção no lago.

Assim, é necessário informar ao modelo o nível d'água em uma condição de contorno, no caso, a barragem do Paranoá. A CEB opera uma estação de monitoramento de nível, com dados diários. Estes não se encontram disponíveis no banco HIDROWEB da ANA, de forma que foram solicitados à CEB por meio do e-SIC do Governo do Distrito Federal (Lei de Acesso à Informação), disponível em https://www.e-sic.df.gov.br/Sistema.

A série histórica de níveis d'água do Lago Paranoá junto à barragem, no período de 1o de julho de 2004 a 31 de outubro de 2016, é mostrada na Figura 6. 


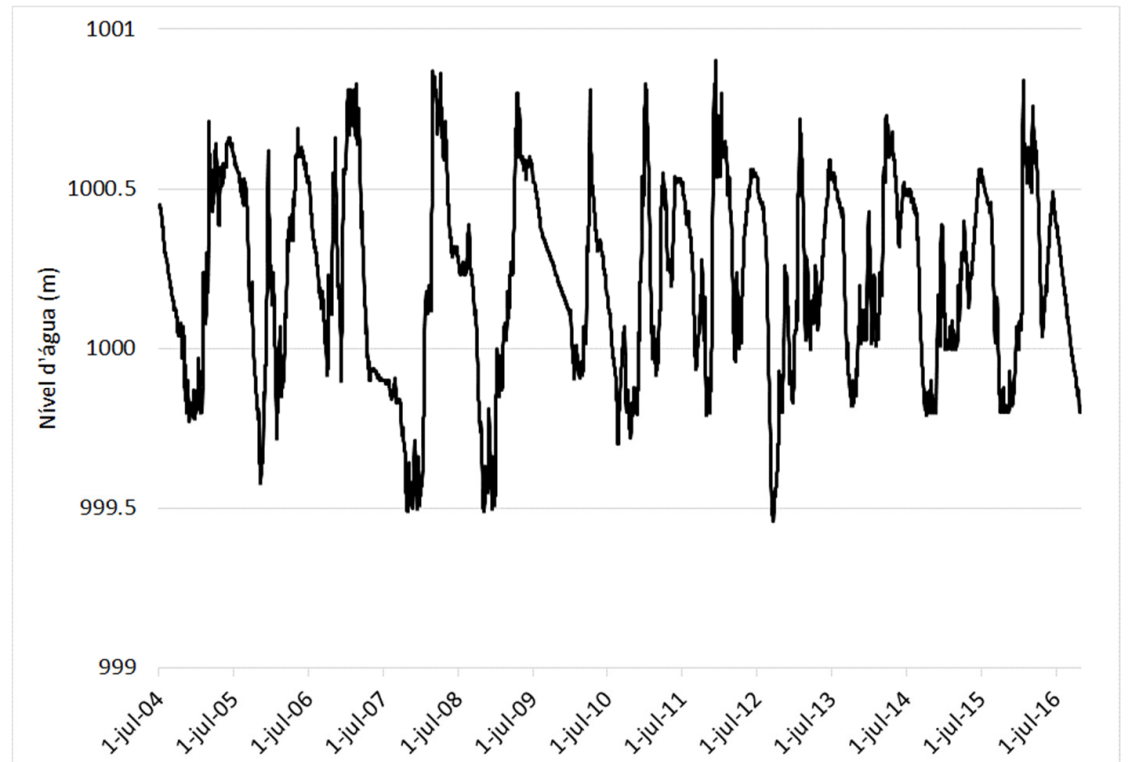

Figura 11. Histórico de níveis d'água do Lago Paranoá junto à barragem, disponibilizado pela CEB

Esta série de níveis foi inserida no modelo HEC-RAS como condição de contorno de jusante, para simulação do modelo hidrodinâmico e de qualidade de água.

\subsubsection{Dados meteorológicos}

Os dados meteorológicos são usados no HEC-RAS para o balanço de energia necessário para a simulação da temperatura da água. São necessários: dados de temperatura do ar, umidade relativa, pressão atmosférica, velocidade do vento, nebulosidade e radiação solar incidente no solo.

A série histórica de dados meteorológicos diários foi obtida por meio do banco de dados BDMEP, gerido pelo Instituto Nacional de Meteorologia (INMET). Esse banco disponibiliza o histórico de monitoramento meteorológico para fins de pesquisa.

A exceção são os dados de radiação solar incidente, que não estão disponíveis no BDMEP. Para calculá-la, foi feita uma estimativa a partir do tempo de insolação diário, este sim disponível no BDMEP, conforme o equacionamento descrito em Collischonn (2001).

A radiação incidente na superfície terrestre é dada por:

$$
S_{\text {sup }}=\left(a_{s}+b_{s} \cdot \frac{n}{N}\right) \cdot S_{\text {top }}(\text { Equação } 1)
$$

Onde $\mathrm{n}$ é a insolação medida (horas por dia), $\mathrm{N}$ é a insolação máxima possível para o dia

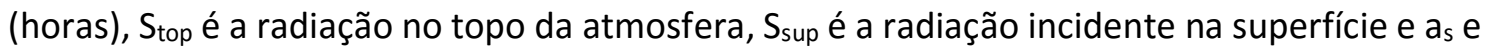


$b_{s}$ são parâmetros que regem a partição da radiação em dias encobertos e claros, respectivamente.

Conforme Collischonn (2001) apud Shuttleworth (1993), os valores recomendados para $\mathrm{a}_{\mathrm{s}} \mathrm{e}$ $b_{s}$ são 0,25 e 0,50, respectivamente.

A insolação máxima diária em um dado ponto do planeta, considerando que o céu está sem nuvens, é dado por:

$$
N=\frac{24}{\pi} \cdot \omega_{s}
$$

onde $\omega_{\mathrm{s}}$ é o ângulo do sol ao nascer (em radianos), que depende da latitude do local e da declinação solar:

$$
\omega_{s}=\arccos (-\tan \varphi \cdot \tan \delta)
$$

onde $\varphi$ é a latitude do local e $\delta$ é a declinação solar (ambos em radianos), esta última dada por:

$$
\delta=0,4093 \cdot \operatorname{sen}\left(\frac{2 \cdot \pi}{365} \cdot J-1,405\right)
$$

onde J é o dia no calendário Juliano (contado a partir de 1으 de janeiro).

A radiação no topo da superfície também depende da latitude e da época do ano, e é calculada por:

$$
S_{\text {top }}=15,392 \cdot \frac{\rho_{w} \cdot \lambda}{1000} \cdot d_{r} \cdot\left(\omega_{s} \cdot \operatorname{sen} \varphi \cdot \operatorname{sen} \delta+\cos \varphi \cdot \cos \delta \cdot \operatorname{sen} \omega_{s}\right)
$$

Onde $\lambda$ é o calor latente de vaporização (em $\mathrm{MJ} / \mathrm{kg}), \rho_{\mathrm{w}}$ é a massa específica da água $\left(\mathrm{kg} / \mathrm{m}^{3}\right)$ e dr é a distância relativa da terra ao sol, dada por:

$$
d_{r}=1+0,033 \cdot \cos \left(\frac{2 \cdot \pi}{365} \cdot J\right)
$$

Embora os dados históricos de radiação não estejam disponíveis, o INMET possui piranômetros (medidores de radiação incidente) que disponibilizam o dado de radiação em tempo real, bem como as medições dos últimos 365 dias. Assim, foi possível comparar a estimativa dada pela Equação 1 com as medições ao longo de alguns meses de 2016, de forma a validar essa estimativa. 


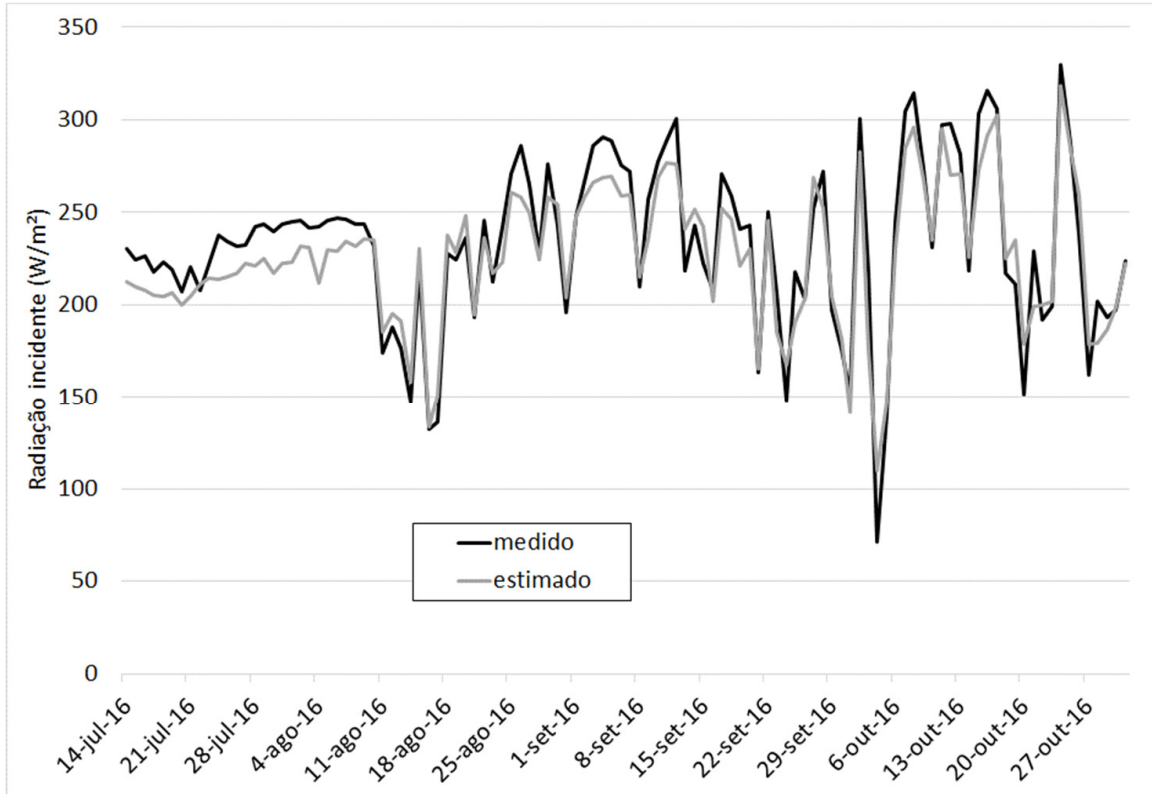

Figura 12. Comparação da radiação estimada com a radiação medida na estação do INMET em Brasila

Pode-se observar que de modo geral a estimativa de radiação incidente é bastante aderente com o que foi medido pelo INMET. Há uma subestimativa em dias ensolarados, como o período em julho/agosto de 2016, porém em dias nublados há uma leve tendência de superestimativa. De modo geral, considera-se que essa estimativa é bastante confiável, dadas as demais incertezas relacionadas com os dados de entrada do modelo.

\subsubsection{Qualidade de água nos tributários}

O histórico de monitoramento de qualidade de água nos afluentes é muito importante, pois representa o aporte direto de poluentes ao lago por meio dos tributários. Essa informação foi obtida junto à CAESB por meio da Escola Corporativa daquela Companhia, com o apoio dos engenheiros Vanusa Monteiro, Wilde Lima e Maria do Carmo Magalhães Cezar e da estagiária Camila Moraes.

Os dados de qualidade nos tributários são monitorados com uma frequência de uma amostra por mês, aproximadamente. Como a simulação no HEC-RAS adota intervalo de tempo diário, é necessário gerar séries de dados de entrada com essa discretização temporal. Assim, as séries diárias foram obtidas por interpolação linear entre os dados existentes.

Para muitos parâmetros, as medições passaram a ser feitas somente a partir de 2007, de forma que os dados para simulação no período de 2004 a 2007 tiveram que ser preenchidos de alguma forma. Optou-se por preencher usando as médias mensais do parâmetro, obtidas 
no período de monitoramento, partindo-se do pressuposto que existe algum tipo de variação sazonal nos parâmetros de qualidade de água. A Figura 10 mostra um exemplo gráfico do procedimento de interpolação e preenchimento.

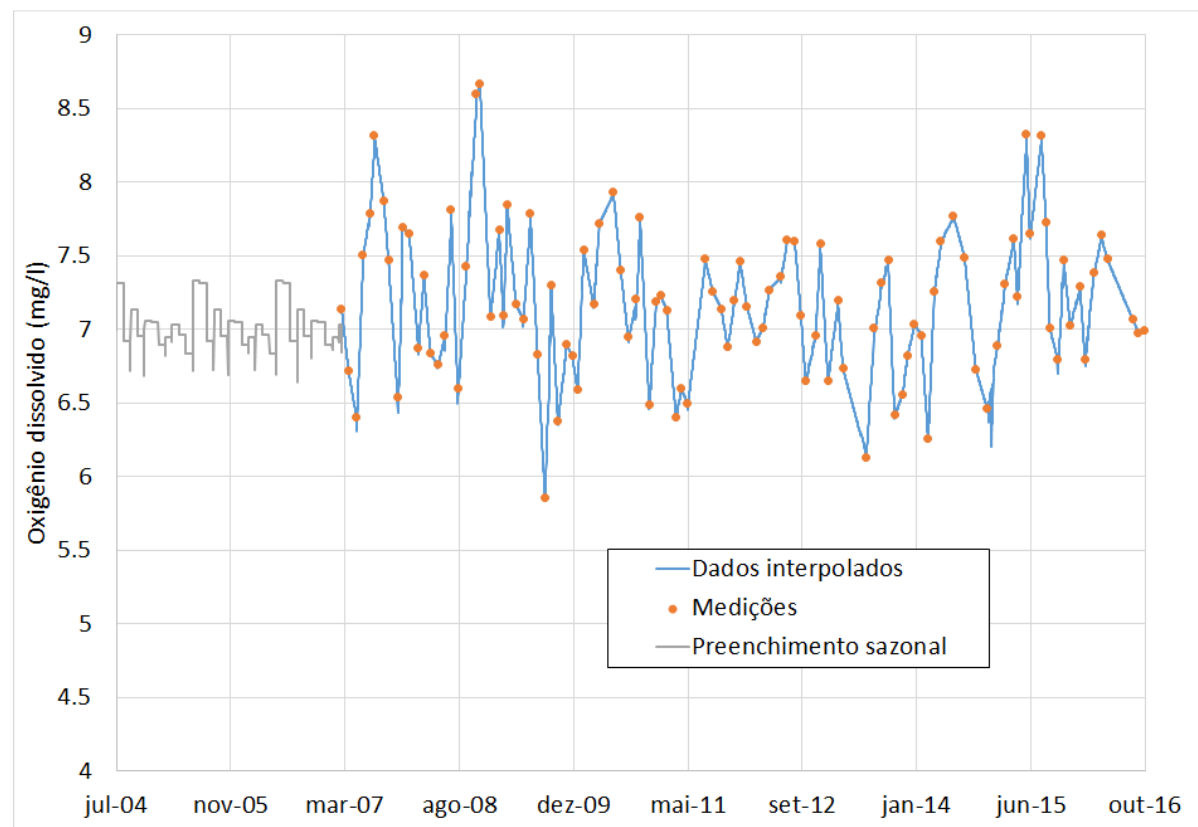

Figura 13. Exemplo da interpolação dos dados de qualidade de água e do preenchimento com base em médias mensais

A localização dos pontos de monitoramento dos tributários corresponde aos mesmos pontos monitorados em relação à quantidade de água. Foram obtidos dados dos seguintes parâmetros: temperatura, oxigênio dissolvido, fósforo total e nitrogênio total. Os dados de DBO eram bastante restitos, sendo mais comuns dados de DQO. Tampouco se dispunha de medições da concentração de algas, que são necessárias para a simulação no HEC-RAS. Ao invés disso, foram usados alguns poucos dados de concentração de clorofila-a, que podem ser correlacionados com a concentração de algas, conforme será descrito a seguir.

\section{Algas}

Existem somente quinze medições de clorofila no ribeirão Bananal entre outubro de 2011 e fevereiro de 2013. Portland State University (2017) sugere valores entre 0,01 e 0,4 para a razão entre a massa seca de algas (em $\mathrm{mg} / \mathrm{l}$ ) e a concentração de clorofila (em $\mu \mathrm{g} / \mathrm{l}$ ), ou seja, a massa de algas é entre 10 e 400 vezes maior do que a massa de clorofila. O valor intermediário sugerido é de uma razão de 0,05, ou 50 vezes. 


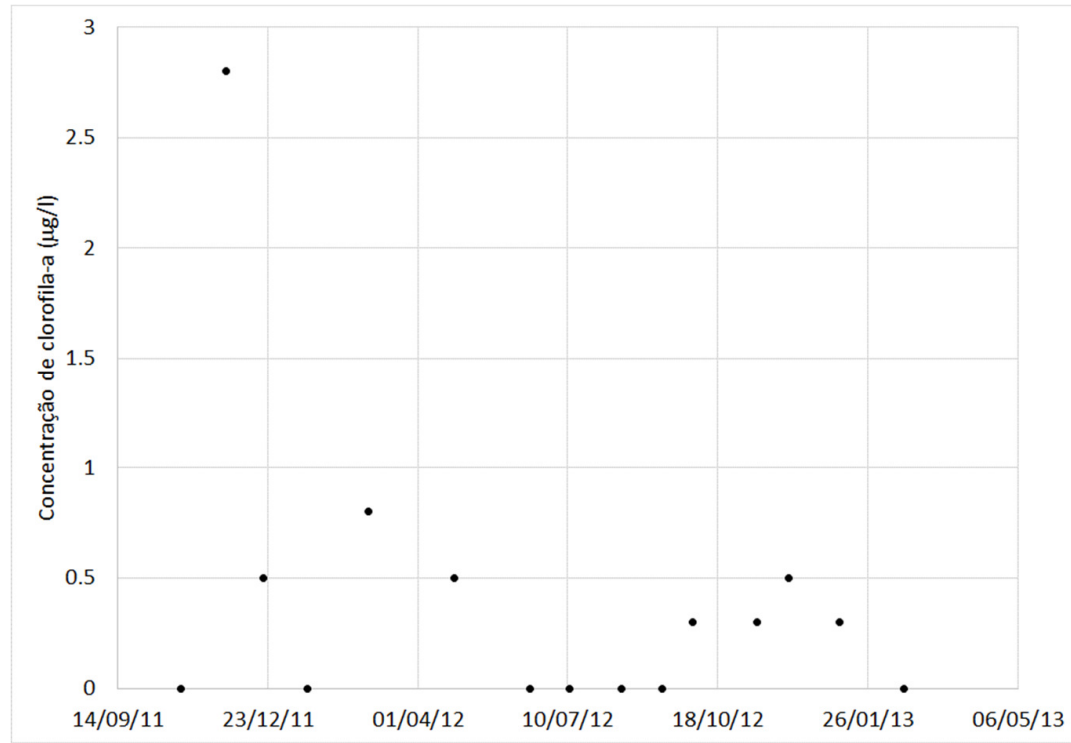

Figura 14. Medições de clorofila-a no ribeirão Bananal

Embora muito limitadas temporalmente e restritas a apenas um dos afluentes do lago, as medições mostram um certo padrão. A concentração de clorofila foi nula em todas as medições realizadas no período de seca (de maio a setembro), e apresentou valores baixos nos demais meses. Esse resultado pode ser explicado pelo fato de que a vazão dos afluentes no período de seca é predominantemente decorrente de escoamento de base (água subterrânea), que normalmente é mais limpa.

Para entrada dos dados no HEC-RAS, adotou-se, de forma simplificada, somente dois valores de clorofila, um para o período de seca (definido como os meses de maio a setembro), com valor nulo, e outro para o período de chuvas (outubro a abril), adotando-se a média das medições realizadas nesses meses, que resultou 0,55 $\mu \mathrm{g} / \mathrm{l}$. Para estimativa da concentração correspondente de algas, multiplicou-se essa concentração por 50.

Esse dado de entrada foi adotado em todos os afluentes do lago, inclusive no Riacho Fundo. Embora esse tributário tenha qualidade de água em geral pior do que os demais, considerase a maior diferença se dêem em termos de carga orgânica (DBO) e não na concentração de algas, assim, considera-se essa hipótese aceitável dada a limitação de dados existentes.

\section{Fósforo}

Com relação ao fósofro, os dados enviados pela CAESB do monitoramento dos afluentes do lago incluem somente a informação do fósforo total, sem discriminar entre as duas formas. Já os dados de monitoramento da ADASA incluem fósforo total e fosfato. A partir desses 
dados, estimaram-se as seguintes partições médias entre fósforo orgânico e inorgânico: $48 \% \times 52 \%$ no Riacho Fundo, 42\%x58\% no Gama, 67\%X33\% no Torto e 37\%x63\% no Bananal. Essa partição foi aplicada a todos os dados da CAESB.

$D B O$

A CAESB dispõe de poucas medições de DBO nos afluentes e no lago, sendo mais frequentes as medições de DQO.

A DQO é sempre maior do que a DBO, por um lado por medir o teor necessário de oxigênio para oxidar substâncias químicas (além da matéria orgânica), e por outro devido ao próprio método de determinação da DQO, que utiliza uma substância oxidante bastante forte, que tende a superestimar a demanda real de oxigênio.

O primeiro fator tende a ter pouca importância no caso do lago Paranoá e de seus afluentes, uma vez que são inexpressivas as indústrias que lançam efluentes na bacia. Assim, a diferença entre DBO e DQO tende a ser pequena, devida somente à diferença de medição. A exceção talvez seja o riacho fundo, que devido à drenagem urbana possivelmente carregue maior numero de poluentes não orgânicos.

Assim, nos períodos em que se dispunha somente de dados de DQO, adotou-se uma relação de $50 \%$ para DBO/DQO.

No caso do Riacho Fundo, a CAESB dispõe de medições em outros pontos mais a montante, devido à ETE Riacho Fundo. A estação 050 é a estação mais a jusante, e dispõe de maior número de medições de DBO. Neste caso usaram-se os dados desta estação, mesmo sabendo que existe alguma autodepuração até a confluência com o lago.

\section{Nitrogênio}

O monitoramento da CAESB informa somente a concentração de nitrogênio total. Já os dados da CAESB apresentam nitrogênio total e nitrogênio amoniacal. Considerando que o nitrogênio total corresponde à soma do amoniacal com nitrogênio orgânico, a partir dos dados da ADASA calculou-se que em média $25 \%$ do nitrogênio total corresponde à amônia, no caso do Riacho Fundo. Com isso foi possível particionar os demais dados monitorados pela CAESB. Nos demais afluentes, pela mesma metodologia, considerou-se a seguinte partição entre 
nitrogênio amoniacal e nitrogênio total: $10 \%$ no Ribeirão Bananal, $30 \%$ no Ribeirão Torto e $20 \%$ no Ribeirão do Gama.

\subsubsection{Vazão e qualidade dos efluentes das ETEs}

Os dados de vazão e qualidade do efluente das ETES foram obtidos por meio da escola corporativa da CAESB. Embora tenham sido solicitados dados diários, a CAESB forneceu somente volumes mensais de efluente, bem como concentrações médias mensais de DBO, nitrogênio total e fósforo total. Para os demais parâmetros, foi necessário arbitrar valores com base na literatura, conforme será visto nesse item.

Como o modelo desenvolvido será simulado em intervalo diário, foi necessário discretizar os dados mensais para valores diários. Para isso, foi arbitrada a todos os dias de um dado mês a média do mês correspondente, conforme Figura 8.

30

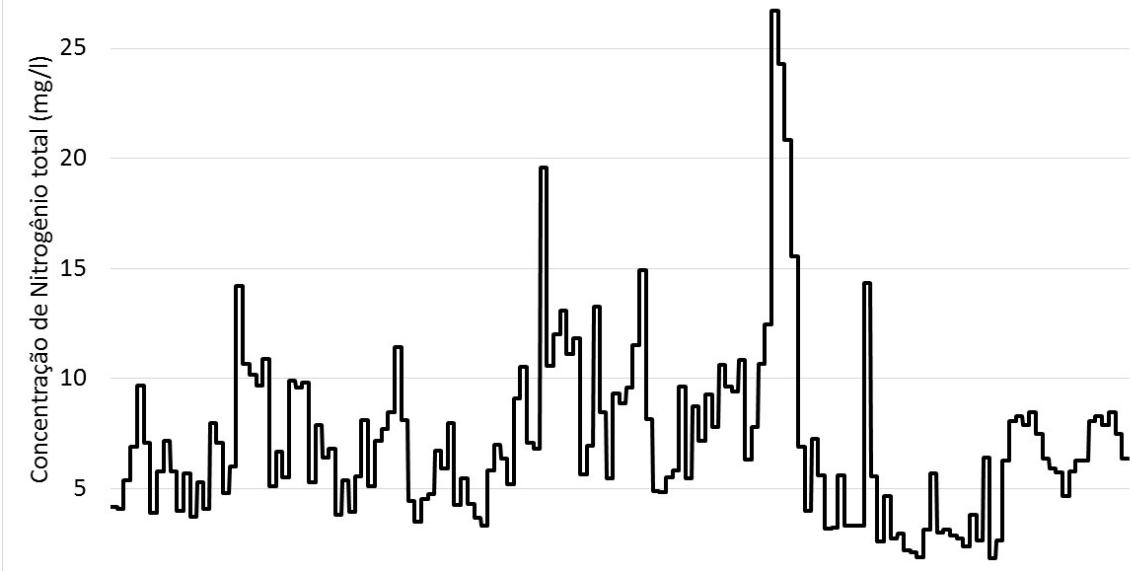

0

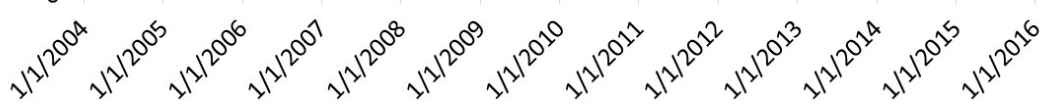

Figura 15. Série diária para a concentração de nitrogênio total na ETE Norte. Note-se os patamares resultantes da adoção da média mensal

A vazão e concentração efluente da ETE foram simulados no HEC-RAS como uma condição de contorno de afluência lateral (lateral inflow hydrograph). 


\section{Algas}

Os dados enviados pela CAESB referentes aos efluentes das ETEs sul e norte não possuem informações referentes a concentrações de algas ou clorofila. Assim, adotou-se uma concentração nula de algas na vazão desses efluentes.

\section{Fósforo}

Com relação ao fósforo, os dados da CAESB contemplam somente o fósforo total, enquanto a entrada do HEC-RAS requer concentrações de fósforo orgânico e de ortofosfato (inorgânico). Supondo que a concentração total corresponde à soma de ambos, é necessário adotar um percentual de partição entre as duas formas.

Von Sperling (1996) sugere que a concentração de fósforo orgânico em esgotos sanitários situa-se entre 1-6 mg/l, com valor típico de $2 \mathrm{mg} / \mathrm{l}$, enquanto a de fósforo inorgânico situa-se entre 3 e $9 \mathrm{mg} / \mathrm{l}$, com valor típico de $6 \mathrm{mg} / \mathrm{l}$. Essas concentrações referem-se a esgotos brutos, de forma que não necessariamente refletem a partição em esgotos tratados a nível terciário, como nas ETEs da CAESB. Ainda assim, como não se possuem outras informações, adotou-se essa partição, ou seja, $25 \%$ do fósforo total é considerado fósforo orgânico, enquanto os restantes $75 \%$ são considerados como ortofosfatos.

\section{Oxigênio dissolvido}

Com relação ao oxigênio dissolvido, Von Sperling (1996) afirma que as concentrações de oxigênio dissolvido em esgotos brutos são normalmente próximas de zero, devido ao consumo de oxigênio decorrente da grande quantidade de matéria orgânica. O mesmo vale para esgotos tratados em nível primário e para tratamento anaeróbio.

No caso de esgotos tratados em nível terciário, com lodos ativados, como é o caso das ETEs da CAESB, o autor afirma que alguma aeração pode ocorrer nos vertedores de saída dos decantadores secundários, podendo o OD subir a $2 \mathrm{mg} / \mathrm{l}$ ou mais.

O autor nota ainda que, caso o emissário de lançamento final for longo, este oxigênio pode ser consumido, devido à DBO remanescente do tratamento. 
Considera-se que esta última observação não se aplica às ETES norte e sul, que se encontram muito próximas ao corpo receptor, de forma que adota-se uma concentração de oxigênio dissolvido constante no efluente, igual a $2 \mathrm{mg} / \mathrm{l}$.

\section{Nitrogênio}

Assim como no caso do fósforo, os dados enviados pela CAESB para a concentração de nitrogênio nos efluentes contemplam somente a concentração TKN (nitrogênio total Kjeldahl), que corresponde à soma do nitrogênio orgânico com a amônia. Assim, é necessário arbitrar uma partição para esses valores.

Liporoni (2012) obteve dados de amônia nos efluentes das etes norte e sul, no período de julho de 2007 a julho de 2008, com concentração média de 3,42 mg/l na ETE norte e 11,38 $\mathrm{mg} / \mathrm{l}$ na ETE sul no período.

Já os dados informados pela CAESB dão conta de uma concentração média de TKN, no mesmo período, de 6,1 mg/l e 13,1 mg/l, respectivamente. Assim, no período citado a amônia representou $56 \%$ e $87 \%$ do TKN nas ETEs norte e sul, respectivamente. Adotou-se então essa mesma partição para dividir os dados de nitrogênio total em todo o período.

\section{Nitrito e Nitrato}

Tampouco se dispõem de dados de nitrito e nitrato no efluente das ETEs. Liporoni (2012) obteve dados do somatório de nitrito e nitrato no período de julho de 2007 a julho de 2008, com média de $1,87 \mathrm{mg} / \mathrm{l}$ na ETE norte e $0,88 \mathrm{mg} / \mathrm{l}$ na ete sul.

Assim, a concentração de nitrito mais nitrato no período correspondeu a $25 \%$ do TKN na ETE norte e $6 \%$ na ETE Sul. Esses resultados apontam para diferenças na eficiência de oxidação do nitrogênio nas duas ETEs, com a ETE norte apresentando uma taxa de nitrificação mais alta, conforme já apontado por Liporoni (2012). Assim, para estimativa da somatória de nitratos e nitritos nas ETEs, a concentração de TKN informada pela CAESB foi multiplicada por esses fatores.

Resta ainda dividir esse somatório entre as duas formas. Diversos autores, como Wetzel (2001) afirmam que a concentração de nitritos em geral é muito baixa. Assim, de forma arbitrária, assumiu-se que $90 \%$ do somatório corresponde a nitrato e somente $10 \%$ a nitrito. 


\subsubsection{Qualidade de água no lago}

Os dados de monitoramento de qualidade de água do lago Paranoá são necessários para a calibração do modelo. Historicamente, a CAESB monitora a qualidade de água do Lago Paranoá em 5 pontos, denominados de $\mathrm{A}$ a $\mathrm{E}$, correspondentes aos quatro principais braços e um quinto ponto próximo à barragem. Esse histórico de monitoramento foi obtido junto à CAESB por meio da Escola Corporativa daquela Companhia.

Mais recentemente, também a ADASA passou a monitorar qualidade de água no Lago Paranoá, desde 2009 junto à barragem e desde 2015 em diversos pontos ao longo dos braços. O histórico de monitoramento nesses pontos foi solicitado e obtido por meio do e-sic do GDF. A tabela abaixo mostra algumas características dos pontos de monitoramento de qualidade de água obtidos no Lago Paranoá:

Tabela 2. Síntese dos dados de monitoramento de qualidade de água do lago Paranoá

\begin{tabular}{|c|c|c|c|c|}
\hline \multicolumn{5}{|c|}{ Dados obtidos junto à CAESB } \\
\hline Ponto & Coordenada & Braço & $\begin{array}{l}\text { Parâmetros } \\
\text { monitorados }\end{array}$ & Período \\
\hline A5 & $\begin{array}{l}15^{\circ} 49^{\prime} 43^{\prime \prime} \mathrm{S} \\
47^{\circ} 53^{\prime} 7^{\prime \prime} \mathrm{W}\end{array}$ & Riacho Fundo & \multirow{5}{*}{$\begin{array}{lr}\text { Clorofila, } & \text { DBO, } \\
\text { Fósforo } & \text { total, } \\
\text { Nitrogênio } & \text { Total, } \\
\text { Nitrato, } & \text { Nitrito, } \\
\text { Amônio, } & \mathrm{OD}, \\
\text { Temperatura } & \mathrm{e} \\
\text { Temperatura do Ar }\end{array}$} & $\begin{array}{l}\text { Jan/2000 a } \\
\text { Dez/2016 }\end{array}$ \\
\hline B & $\begin{array}{l}15^{\circ} 51^{\prime} 24^{\prime \prime} \mathrm{S} \\
47^{\circ} 51^{\prime} 27^{\prime \prime} \mathrm{W}\end{array}$ & $\begin{array}{l}\text { Gama/Cabeça } \\
\text { de Veado }\end{array}$ & & $\begin{array}{l}\text { Jan/2000 a } \\
\text { Dez/2016 }\end{array}$ \\
\hline $\mathrm{C}$ & $\begin{array}{l}15^{\circ} 47^{\prime} 32^{\prime \prime S} \\
47^{\circ} 48^{\prime} 01^{\prime \prime} \mathrm{W}\end{array}$ & $\begin{array}{l}\text { Paranoá (próx. } \\
\text { Barragem) }\end{array}$ & & $\begin{array}{l}\text { Jan/2000 a } \\
\text { Dez/2016 }\end{array}$ \\
\hline $\mathrm{D}$ & $\begin{array}{l}15^{\circ} 44^{\prime} 05^{\prime \prime S} \\
47^{\circ} 50^{\prime} 50^{\prime \prime} \mathrm{W}\end{array}$ & Torto & & $\begin{array}{l}\text { Jan/2000 a } \\
\text { Dez/2016 }\end{array}$ \\
\hline$E$ & $\begin{array}{l}15^{\circ} 43^{\prime} 41^{\prime \prime S} \\
47^{\circ} 54^{\prime} 36^{\prime \prime} \mathrm{W}\end{array}$ & Bananal & & $\begin{array}{l}\text { Jan/2000 a } \\
\text { Dez/2016 }\end{array}$ \\
\hline \multicolumn{5}{|c|}{ Dados obtidos junto à ADASA } \\
\hline $\begin{array}{l}\text { Barr. Paranoá } \\
(60479230)\end{array}$ & $\begin{array}{l}15^{\circ} 47^{\prime} 50^{\prime \prime} \mathrm{S} \\
47^{\circ} 47^{\prime} 03^{\prime \prime} \mathrm{W}\end{array}$ & Paranoá & \multirow{2}{*}{$\begin{array}{l}\text { Clorofila (desde } \\
\text { 2015), temperatura, } \\
\text { DBO, DQO, Nitrato, } \\
\text { Nitrito (ambos desde }\end{array}$} & $\begin{array}{ll}\text { Ago/09 } & \text { a } \\
\text { nov/16 }\end{array}$ \\
\hline $\begin{array}{l}\text { Baia Rib. Gama } \\
(60478530)\end{array}$ & $\begin{array}{l}15^{\circ} 50^{\prime} 24^{\prime \prime} \mathrm{S} \\
47^{\circ} 51^{\prime} 35^{\prime \prime} \mathrm{W}\end{array}$ & $\begin{array}{l}\text { Gama/Cabeça } \\
\text { de Veado }\end{array}$ & & $\begin{array}{ll}\text { Nov/15 } & \text { a } \\
\text { nov/16 }\end{array}$ \\
\hline $\begin{array}{l}\text { Ponte Costa e } \\
\text { Silva }(60478700)\end{array}$ & $\begin{array}{l}15^{\circ} 49^{\prime} 23^{\prime \prime S} \\
47^{\circ} 52^{\prime} 40^{\prime \prime} \mathrm{W}\end{array}$ & Riacho Fundo & \multirow{2}{*}{$\begin{array}{l}\text { 2010), Nitrogênio } \\
\text { amoniacal, nitrogênio } \\
\text { total, oxigênio } \\
\text { dissolvido, fósforo } \\
\text { total, fosfato. }\end{array}$} & \\
\hline Minas Tênis Clube & $\begin{array}{l}15^{\circ} 45^{\prime} 01^{\prime \prime} \mathrm{S} \\
47^{\circ} 52^{\prime} 04^{\prime \prime} \mathrm{W}\end{array}$ & Bananal & & \\
\hline
\end{tabular}

Os dados da ADASA, em sua maioria, são muito recentes, de forma que foram considerados na calibração do modelo somente aqueles pontos próximos a locais monitorados pela CAESB, de forma a complementar a informação das duas instituições. Nos pontos onde não há 
coincidência, como é o caso da Ponte JK, e nos quais a extensão é curta (desde 2015) os dados não foram levados em conta.

No caso do ponto $C$, próximo à barragem, a CAESB monitora os parâmetros em seis pontos ao longo da mesma vertical: a $1 \mathrm{~m}$ de produndidade, a $5 \mathrm{~m}, 10,15 \mathrm{~m}, 20 \mathrm{~m}$ e próximo ao fundo. Como o modelo adotado é unidimensional, foi necessário promediar essas medições para fins de comparação com os resultados da simulação. Essa média foi calculada de forma ponderada, levando-se em conta a diminuição da seção transversal em pontos mais profundos. A partir de uma seção transversal situada próxima ao ponto de monitoramento, atribuiu-se os seguintes ponderadores para as medições (Figura 8).

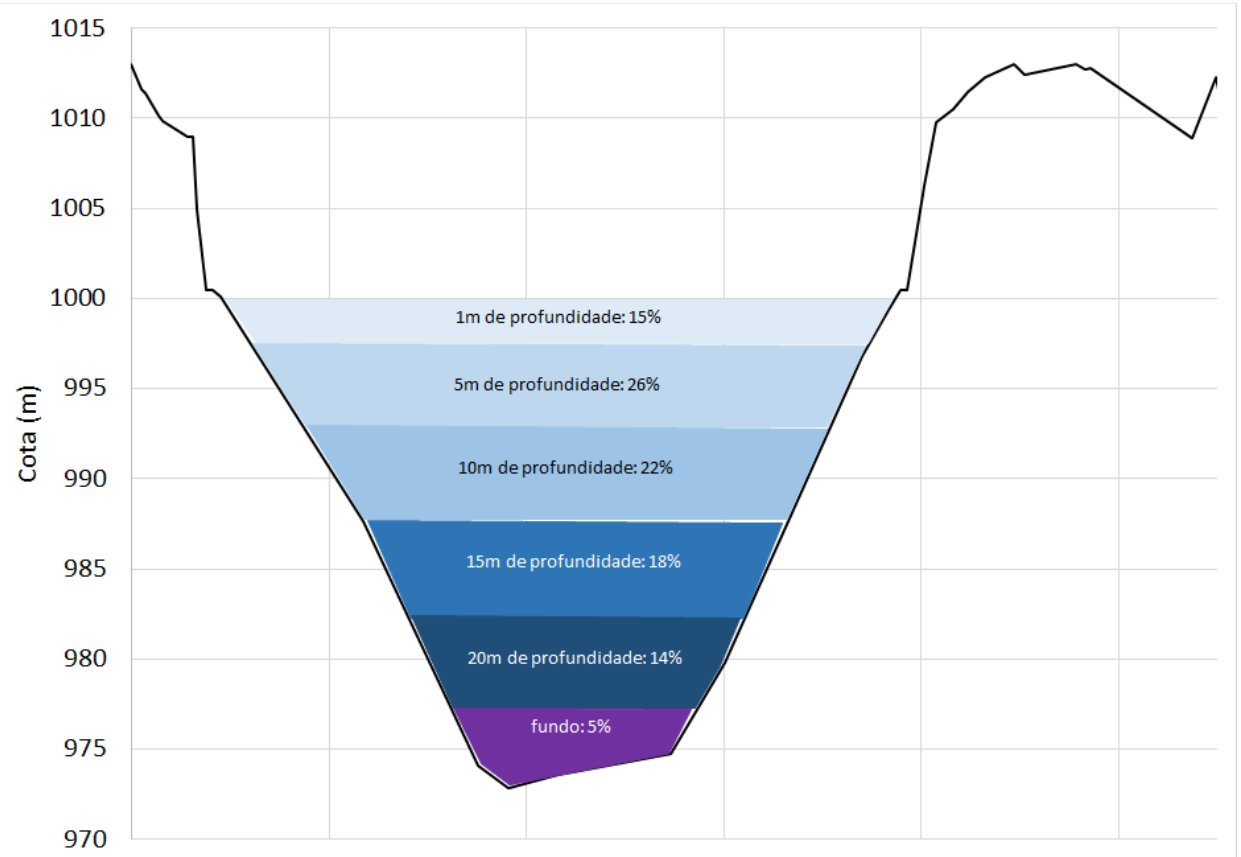

Figura 16. Representação esquemática da ponderação das medições no ponto C ao longo da profundidade da seção

Considerou-se que a medição na superfície era válida para os primeiros $2,5 \mathrm{~m}$ de profundidade, e a medição do fundo válida para os 2,5m acima do fundo. Nos demais pontos, a medição era válida 2,5m acima e 2,5m abaixo da profundidade medida.

Para a conversão de DQO em DBO, de clorofila-a em algas e partição de fósforo, foram adotadas as mesmas premissas adotadas no caso dos tributários. Já para a partição de nitrogênio total em amônio e nitrogênio orgânico, adotou-se uma partição de 50\%×50\%, obtida a partir de dados da ADASA. 


\subsection{Validação em campo}

Além dos principais braços, e dos lançamentos de efluentes das estações de tratamento de esgoto, cujo aporte de vazão e qualidade de água serão inseridos diretamente no modelo a ser desenvolvido, o Lago Paranoá recebe diversos outros lançamentos e contribuições, em pequenos córregos e principalmente devido ao sistema de drenagem pluvial das áreas urbanas em seu entorno.

Diferentemente dos afluentes principais, esses aportes não são monitorados com frequência, de forma que não se tem bom conhecimento das vazões afluentes, nem tampouco da qualidade da água lançada.

Dependendo da sua magnitude, esses lançamentos podem influir de forma expressiva nos resultados do modelo. Assim, visando a uma avaliação mais qualitativa da sua importância, foi realizada uma vistoria em campo a alguns dos principais pontos de lançamento de drenagem pluvial no lago Paranoá. Essa vistoria foi realizada no dia 20/02/2017, após uma semana sem chuvas, e as dimensões das galerias foram medidas com trena.

Foram visitados quatro pontos de lançamento, a saber: ao lado da ETE Sul, ao lado do Clube Nipo, ao lado do IBAMA e Córrego Olhos D’água (drenagem de boa parte da Asa Norte).

O principal lançamento é a galeria ao lado da ETE Sul, que drena boa parte das quadras 13 a 16 da Asa Sul, além do Sudoeste. Tratam-se de duas galerias quadradas com 2,5m de lado, que apresentavam uma baixa vazão no momento da vistoria (estimada visualmente em cerca de $200 \mathrm{l} / \mathrm{s}$ ). Nas proximidades deste ponto houve a floração de cianobactérias em novembro de 2016.

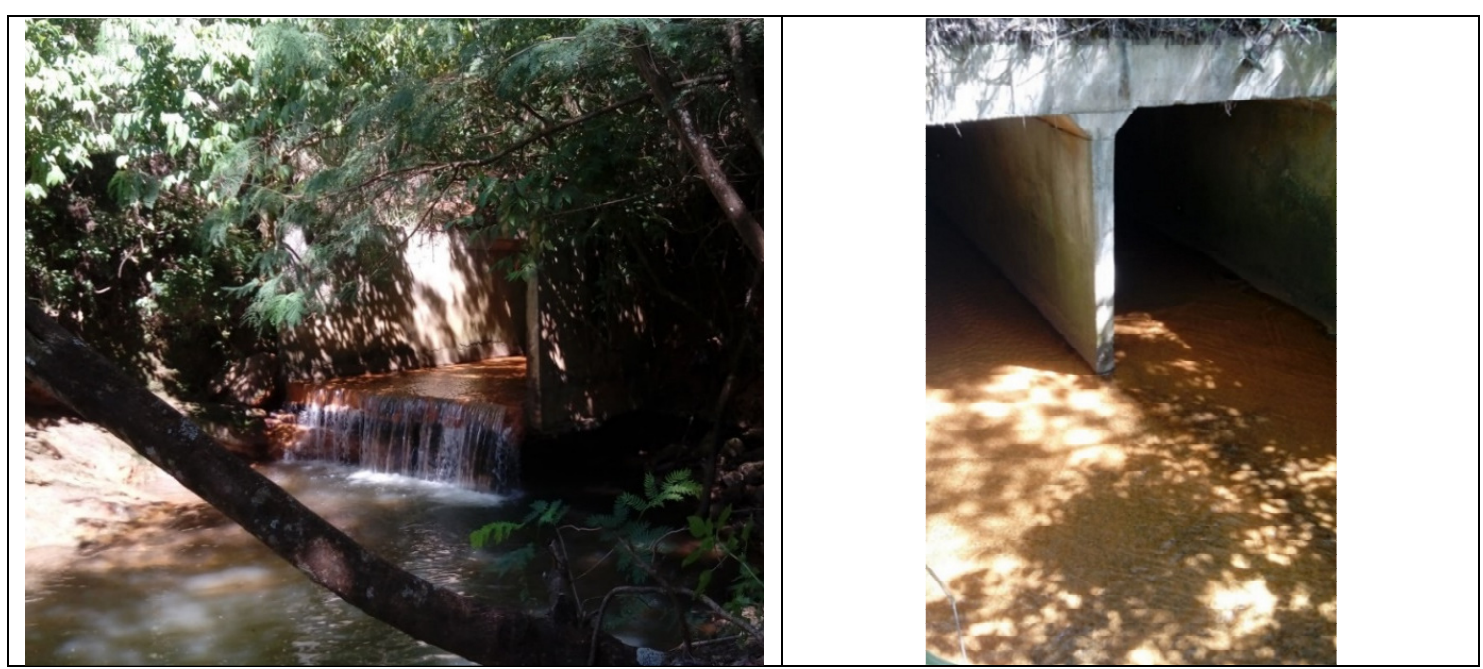

Figura 17. Lançamento da drenagem ao lado da ETE SUl, por meio de duas galerias quadradas de $2,5 m$ 
No ponto ao lado do Clube Nipo, o lançamento se dá por meio de duas manilhas circulares com $1 \mathrm{~m}$ de diâmetro, e a vazão era praticamente nula. Este local recebe a contribuição de algumas superquadras da Asa Sul.

No ponto ao lado do IBAMA, ocorre um lançamento por meio de duas manilhas de $70 \mathrm{~cm}$ de diâmetro, com uma vazão inferior a 50 l/s. Este local recebe a contribuição da drenagem de parte da UNB.

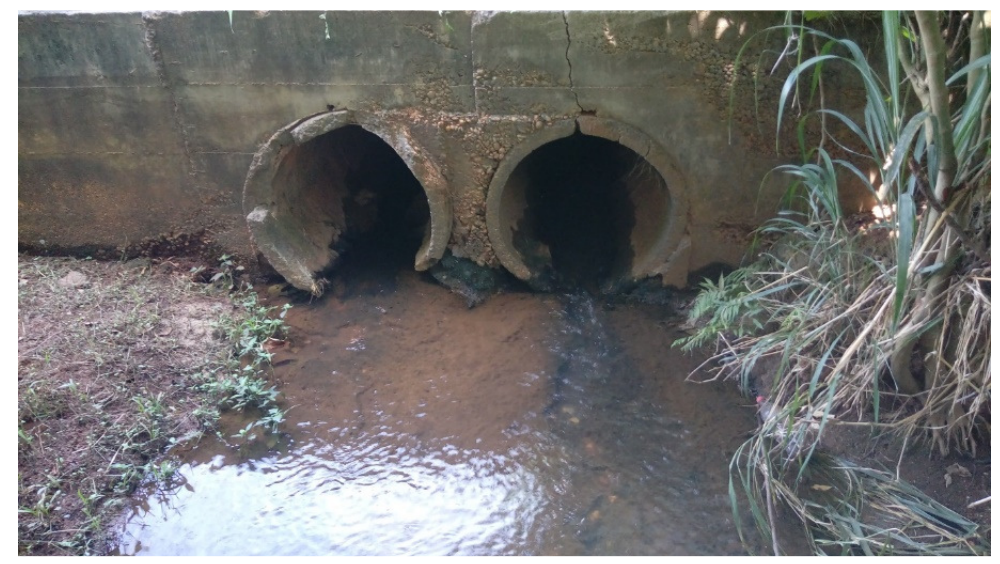

Figura 18. Lançamento de drenagem pluvial ao lado do IBAMA

Já no parque Olhos d'água, o lançamento é feito por meio de duas galerias de seção quadrada com $2 \mathrm{~m}$ de largura e $1 \mathrm{~m}$ de altura, além de uma manilha com $1 \mathrm{~m}$ de diâmetro.

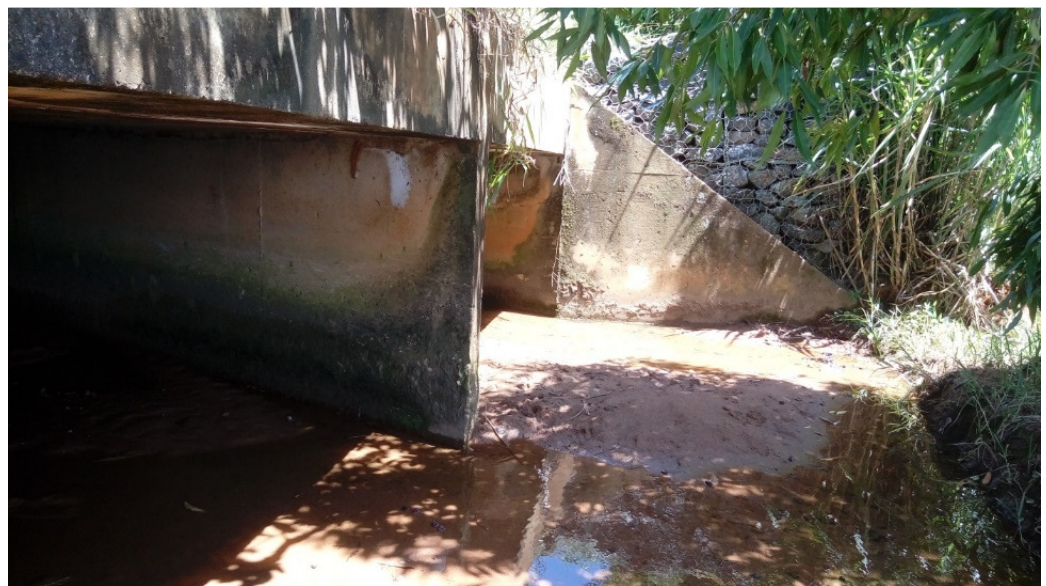

Figura 19. Galerias de seção retangular, lançamento próximo ao parque Olhos d'água

Este ponto recebe a contribuição da drenagem pluvial de boa parte da Asa Norte. Além disso, há um córrego que aflui ao lago neste local (córrego Olhos d'água), de forma que a vazão 
decorre da própria hidrologia natural do córrego. Uma vazão de cerca de 100 l/s foi estimada neste local.

A ocorrência de vazão nas galerias mesmo após uma semana sem chuvas pode ser explicada por infiltração ao longo das galerias, ou então por ligações clandestinas de esgoto doméstico. De qualquer forma, pôde ser constatado que a vazão lançada nestes pontos é bastante baixa frente à vazão dos principais afluentes do lago, pelo menos no período sem chuvas. Além disso, visualmente, na maior parte dos pontos não apresentava odor notável, o que indica que provavelmente não há muitas ligações clandestinas de esgoto doméstico nesse sistema de drenagem.

\subsection{Procedimento de calibração do modelo}

Todos os dados de entrada do modelo consideraram o período de 1ㅇe julho de 2004 a 31 de outubro de 2016. Optou-se por um período longo para que se possa ter uma representatividade estatística dos resultados, contemplando anos mais secos e mais úmidos, operações anômalas das estações de tratamento, etc.

Do período total, foi selecionado um período para calibração, definido entre 1ㅇde julho de 2010 e 31 de outubro de 2013. Esse período foi escolhido por dispor de maior quantidade de dados observados para ajuste (sem interpolação ou preenchimento), e também por ter apresentado uma variação anômala na operação das estações de tratamento de esgoto.

Como já mencionado, o módulo hidrodinâmico do modelo não foi calibrado, tendo sido arbitrado um coeficiente de manning constante para todo o reservatório.

Já o módulo de qualidade de água foi calibrado, primeiramente com respeito à temperatura da água e posteriormente, à dinâmica e transporte de nutrientes.

A calibração da temperatura se deu basicamente por meio da variação dos coeficientes $a, b$ e c, que regulam o efeito do vento nos fluxos de calor sensível e latente. Inicialmente o HECRAS sugere valores de $1 \cdot 10^{-7}$ para os três parâmetros. Porém, a simulação com esses valores levou a uma superestimativa da temperatura na maior parte dos pontos monitorados. Assim, os valores foram aumentados, de forma a aumentar principalmente o fluxo de calor latente (evaporação), e com isso diminuir a temperatura da água.

O procedimento foi iterativo, variando-se um parâmetro e simulando o modelo, verificandose visualmente os resultados em comparação com os dados monitorados nos 5 pontos do 
lago. Procurou-se limitar os valores dos parâmetros à faixa recomendada pelos próprios manuais do programa. Não foram calculados coeficientes de desempenho, como usualmente é feito em modelos hidrológicos, somente um ajuste visual. Deu-se bastante ênfase em um bom ajuste na seção próxima à barragem, uma vez que essa representa a integração de todos os fenômenos no reservatório. Além disso, o ajuste no Riacho Fundo também teve um interesse maior, devido aos eventos recentes de floração de cianobactérias nesse braço e também pelo lançamento da ETE Sul. Menor peso foi dado ao braço do Gama/Cabeça de Veado, uma vez que não existem interferências atuais ou futuras de interesse nesse braço. Já para os braços do Torto e do Bananal se deu uma maior atenção pois nestes braços estão previstas captações futuras de abastecimento de água pela CAESB.

\subsection{Simulação de cenários}

Uma vez ajustado o modelo, foi feita a simulação de um cenário futuro de aumento do uso da água. Dada a preocupação com a possível deterioração da qualidade de água, resultante do aumento das captações no lago, foi elaborado um cenário que contempla as duas captações emergenciais em implantação pela CAESB. A primeira está situada no ribeirão Bananal, fora do Lago, porém com efeitos na diminuição das vazões afluentes a este braço. A segunda encontra-se no braço do Torto, próximo à quadra ML4 do Lago Norte. Não se teve acesso a informações mais detalhadas desses projetos, entretanto as notícias veiculadas na imprensa dão conta de que ambos os projetos contemplam uma vazão captada de $700 \mathrm{l} / \mathrm{s}$ cada.

Para simular a retirada do Bananal, simplesmente diminui-se uma vazão de $700 \mathrm{l} / \mathrm{s}$ de todos os valores da série de vazões afluentes a esse braço (condição de contorno). Entretanto, em alguns intervalos de tempo a vazão naturalmente já é inferior a esse valor. Nesses casos considerou-se que a vazão remanescente mínima a ser mantida ao lago deveria ser de $50 \mathrm{l} / \mathrm{s}$, ou seja, a vazão afluente nunca foi inferior a esse valor. A concentração dos parâmetros de qualidade de água não foi alterada nesse cenário.

Já a retirada no braço do Torto foi representada, de forma simplificada, por meio de um vertedor lateral (lateral structure) fictício, conforme estrutura disponível no HEC-RAS. Não foram inseridas as dimensões desse vertedor fictício. Ao invés disso, a operação da derivação 
foi definida por meio de uma curva-chave (relação entre níveis do lago e vazões derivadas), conforme Figura 12.

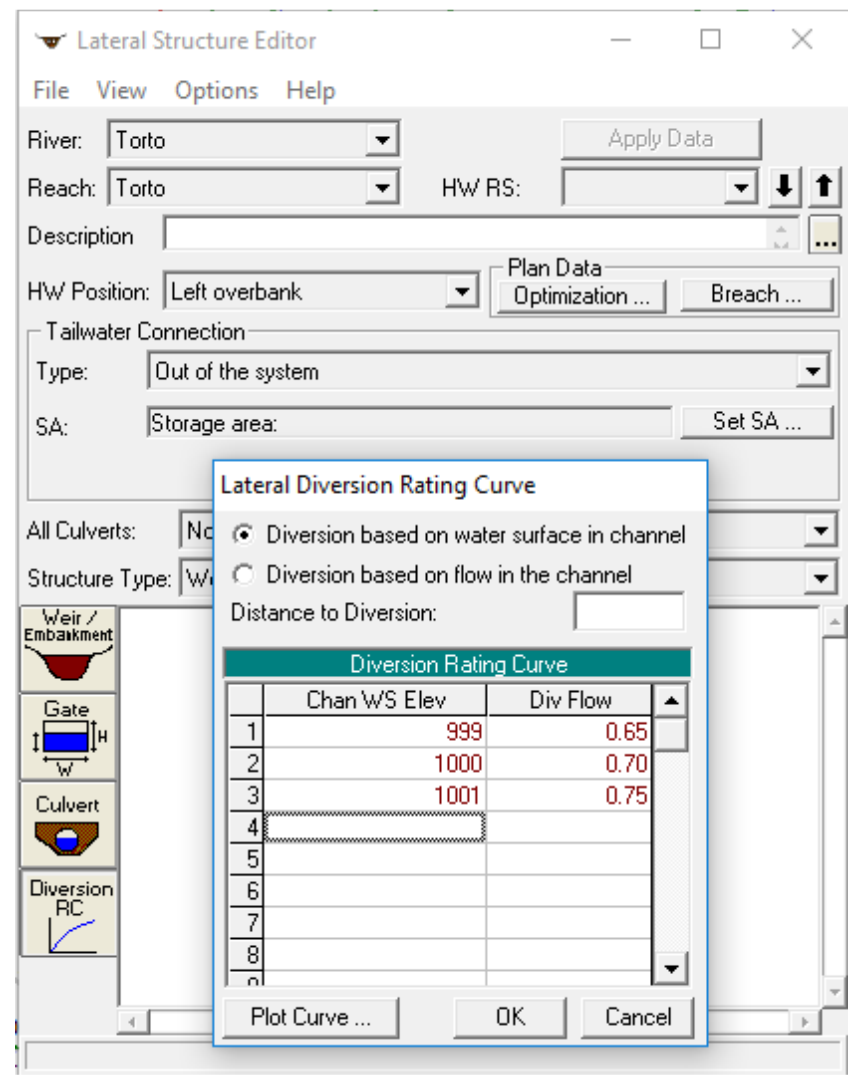

Figura 20. Representação no HEC-RAS da captação de água no braço do Torto

A rigor essa captação deverá se dar por bombeamento, e não por meio de um vertedor. No entanto, para os fins do presente estudo, essa simplificação não causa qualquer problema. Foi considerada uma pequena variação da vazão retirada, em função do nível d'água do lago, de forma a representar de forma simplificada a variação da operação da bomba em diferentes níveis.

Para avaliar o impacto, os resultados da simulação deste cenário foram comparados aos resultados do modelo ajustado, em termos da variação média de cada parâmetro de qualidade de água, de forma a verificar se houve piora da qualidade nos diversos braços, e em que magnitude. 


\section{Resultados e Discussão}

\subsection{Calibração e validação do modelo}

A seguir são apresentados os resultados do modelo nas diversas seções monitoradas e para diversos parâmetros. Em cada local, são apresentados em um gráfico a série histórica simulada, resultante do modelo, e os dados observados. Como se tratam de muitos locais/parâmetros, são mostrados apenas alguns de maior interesse.

\subsubsection{Temperatura}

Os dados observados nos afluentes do lago e nos correspondentes braços mostram que o represamento provoca um aumento da temperatura da água. Em todos os braços, a temperatura da água é superior à do tributário que contribui ao braço, conforme pode ser visto no exemplo do braço do Bananal, mostrado na Figura 14

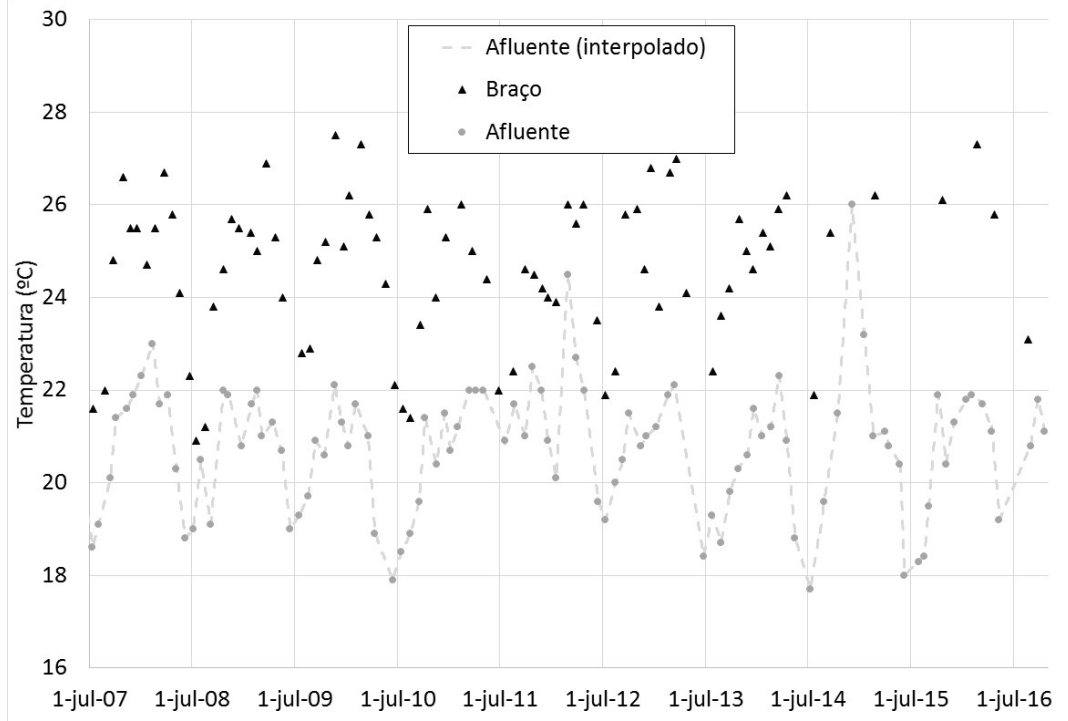

Figura 21. Comparação entre temperatura da água no ribeirão Bananal e no braço do Bananal, mostrando o efeito de aumento da temperatura causado pelo Lago

Esta primeira observação sinaliza que o balanço energético do lago Paranoá é positivo, ou seja, recebe uma quantidade de calor maior do que emite. As principais fontes de energia no HEC-RAS são a radiação absorvida e o fluxo de calor sensível (quanto o ar está mais quente do que a água). Os principais sumidouros são o fluxo de calor sensível (quando a água está mais quente do que o ar) e de calor latente (evaporação), e em menor medida, a radiação de onda longa. 
A Figura 15 mostra os resultados do modelo para o parâmetro temperatura no braço do Ribeirão Bananal, próximo ao Minas Tênis Clube.

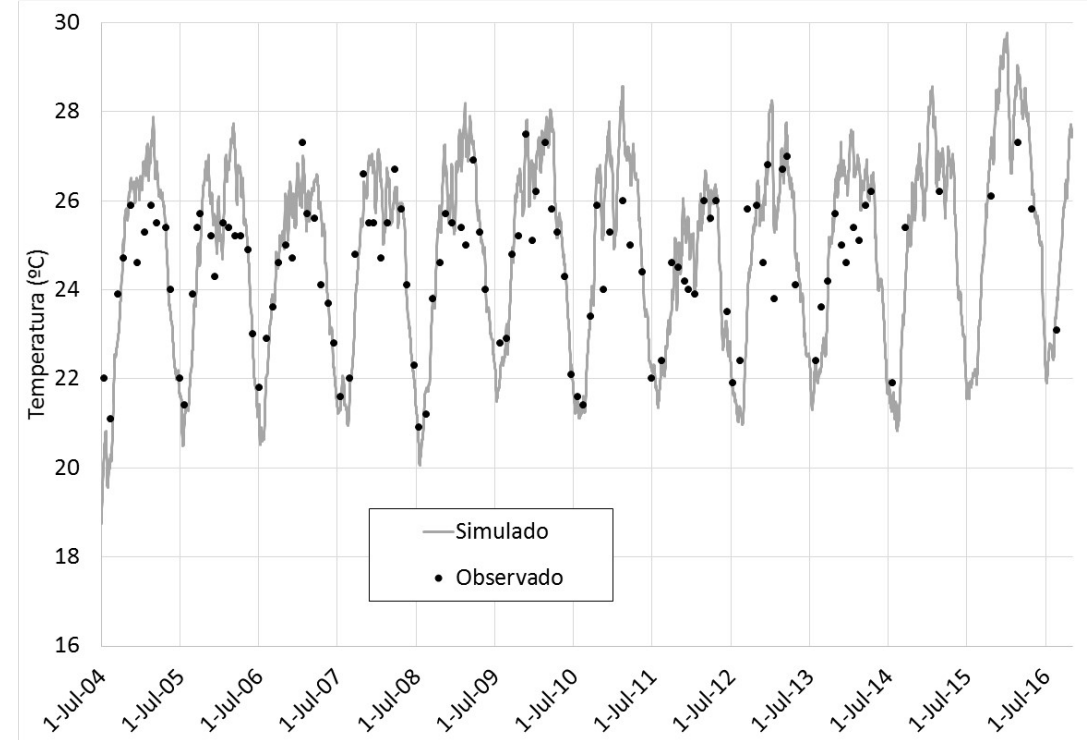

Figura 22. Resultados para o parâmetro temperatura no braço do Bananal (ponto E3 - Minas Tênis)

Pode-se observar que o modelo HEC-RAS representa de forma adequada a variação de temperatura nesta porção do Lago Paranoá, que apresenta uma sazonalidade. Também a variação interanual (de um ano para outro) foi razoavelmente bem representada pelo modelo, com anos de água mais fria (2008, por exemplo) e mais quente (2015/2016). A temperatura média resultante do modelo neste ponto foi de $24,88^{\circ} \mathrm{C}$, enquanto a média das medições foi de 24,54 ํ C.

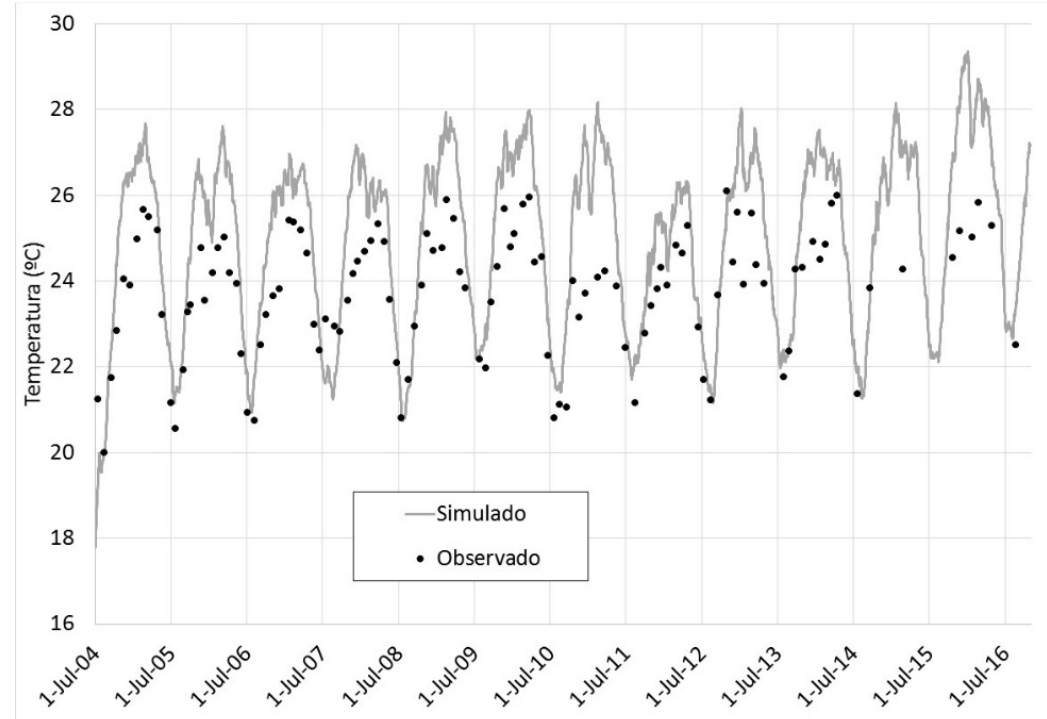

Figura 23. Resultados do modelo para temperatura próximo à barragem do Paranoá (ponto C) 
Neste ponto, junto à barragem, os resultados não foram tão bons quanto nos braços. 0 modelo superestimou a temperatura da água, em especial nos meses de verão. Possivelmente isso tenha a ver com deficiências da modelagem unidimensional em um ambiente com estratificação térmica, como é o caso desse trecho em particular do lago Paranoá. É possível também que haja afluências subterrâneas no lago (não levadas em conta no modelo) que contribuam para uma diminuição da temperatura.

A média das temperaturas simuladas foi de 25 으, enquanto a média das observações foi de 23,55으. Naturalmente, poderia ser obtido um melhor resultado neste ponto, por meio da alteração dos parâmetros que causam uma maior perda de calor da água, entretanto isso pioraria os resultados nos braços. Assim, de modo geral considera-se que o modelo tem uma representação aceitável da realidade.

\subsubsection{Oxigênio dissolvido}

No caso do oxigênio dissolvido, houve um ajuste razoável na maior parte dos braços, com o modelo subestimando a concentração desse parâmetro em $5 \%$ a $16 \%$ em média. No ponto próximo à barragem, por outro lado, o modelo superestimou o oxigênio dissolvido em $21 \%$ na média. A Figura 24 mostra os resultados do modelo para este parâmetro em dois locais: no braço do Torto e próximo à barragem.

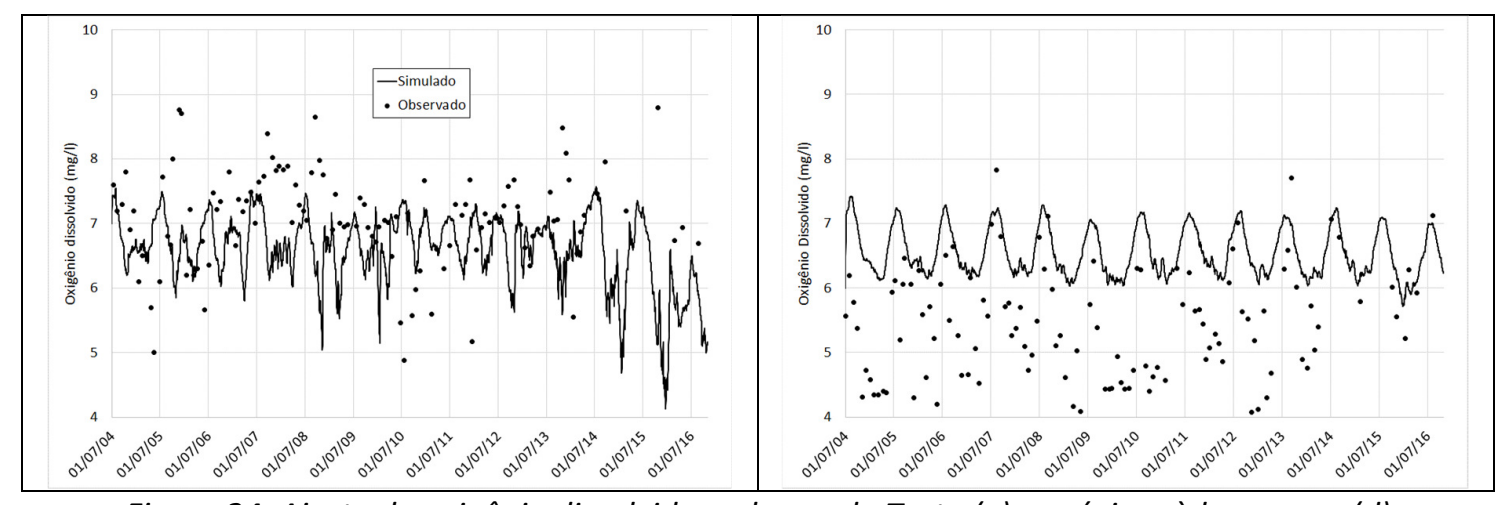

Figura 24. Ajuste do oxigênio dissolvido no braço do Torto (e) e próximo à barragem (d)

O resultado do braço do Torto é representativo dos demais braços. Observa-se que em termos médios, o modelo chegou a concentrações próximas às medidas neste e em outros braço. Pelos resultados, pode-se observar que há uma queda nas concentrações medidas de oxigênio dissolvido próximas à barragem, em relação aos braços. Ressalta-se que somente neste ponto a CAESB monitora o parâmetro em várias profundidades, enquanto nos braços o monitoramento se dá somente próximo à superfície. Esse resultado aponta para a 
possibilidade de que haja uma variação vertical do oxigênio também nos braços, que não é capturada pelas medições. Essa possibilidade deveria ser melhor investigada, e se for o caso, o modelo deveria ser reajustado de forma a resultar em concentrações menores de oxigênio nos braços.

\subsection{3. $\mathrm{DBO}$}

No caso da DBO, o modelo subestimou o valor do parâmetro em todos os pontos de monitoramento. A Figura 25 mostra o resultado para este parâmetro no ponto de monitoramento junto à barragem do Paranoá, bem como os limites de concentração das classes previstas na Resolução CONAMA n³57/2005

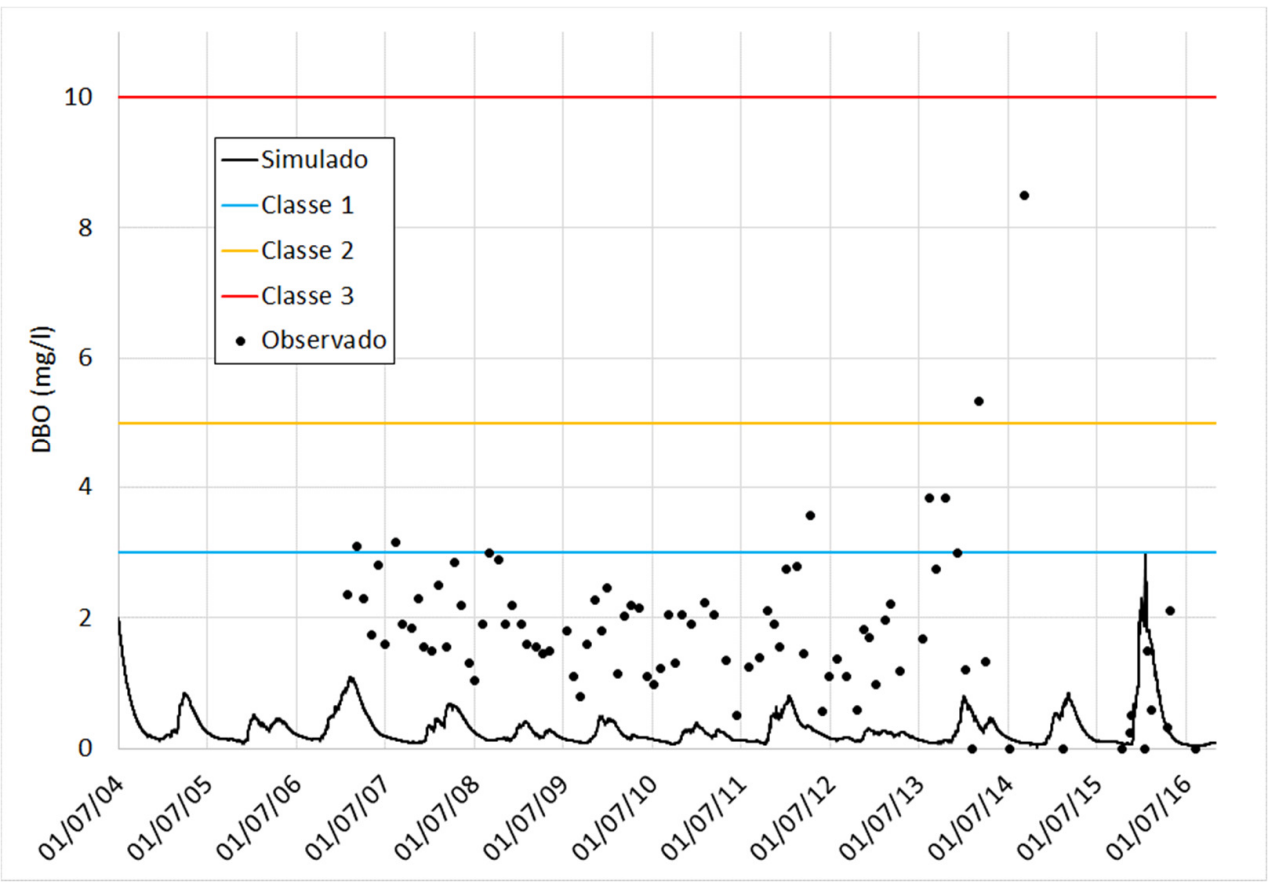

Figura 25. Resultados para o parâmetro DBO próximo à barragem

Algumas ressalvas devem ser feitas a esses resultados. Em primeiro lugar, na maior parte dos casos não se dispunha de medições de DBO, somente de DQO, a partir das quais estimou-se uma fração correspondente à DBO. Assim, não necessariamente os valores observados correspondem à realidade. No período mais recente, em que se dispõe de medições de DBO da ADASA, o modelo ficou bastante aderente, com concentrações bastante baixas.

Além disso, constata-se que as eventuais incertezas numéricas das concentrações resultantes do modelo não trazem consequências práticas do ponto de vista do gerenciamento de recursos hídricos. Isto porque tanto os dados observados quanto os simulados apontam para concentrações bastante baixas desse poluente, sinalizando para uma boa qualidade da água. 
De fato, tanto as concentrações simuladas quanto a maior parte das concentrações observadas são inferiores ao limite da classe 1, que permitiria usos mais nobres para a água do lago.

O ajuste deste parâmetro no HEC-RAS não é trivial, uma vez que a DBO só possui sumidouros, de tal forma que sua concentração tende a diminuir indefinidamente, a menos que haja lançamentos pontuais.

\subsubsection{Algas}

O modelo ajustado levou a concentrações simuladas médias inferiores às estimadas a partir das observações, em todos os pontos monitorados. A Figura 26 mostra os resultados para este parâmetro, no ponto de monitoramento próximo à barragem do Paranoá

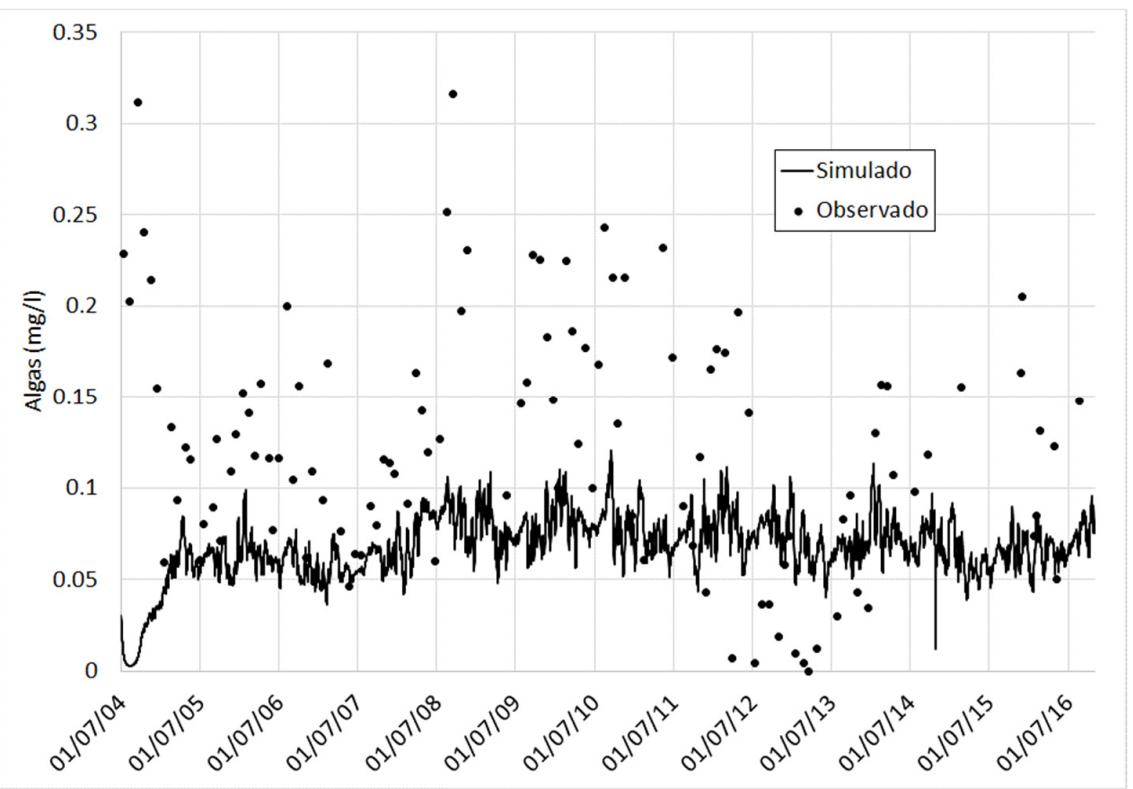

Figura 26. Resultados para a concentração de algas próximo à barragem

Deve-se ressaltar que as observações desse parâmetro não são medições diretas, e sim estimativas a partir da concentração de clorofila, assumindo-se uma fração constante entre ambas. Assim, os resultados para este parâmetro são altamente incertos. Ainda assim, podese considerar um resultado satisfatório, visto que os resultados simulados encontram-se na mesma ordem de grandeza das estimativas.

A incerteza na real concentração de algas tem impactos importantes em todo o ciclo de nutrientes que é modelado pelo HEC-RAS, como será visto nos próximos resultados. 


\subsubsection{Nitrogênio}

No caso do nitrogênio, ajustes razoáveis foram obtidos para nitrogênio orgânico e amoniacal. Na maior parte dos pontos, o modelo subestimou esses parâmetros, mas gerou resultados da mesma ordem de grandeza. Porém os resultados para nitrato e nitrito foram bastante ruins. O modelo superestimou bastante as concentrações.

A Figura 27 mostra o resultado para o parâmetro nitrogênio amoniacal, no ponto junto à barragem. Resultados similares foram obtidos para os braços do reservatório.

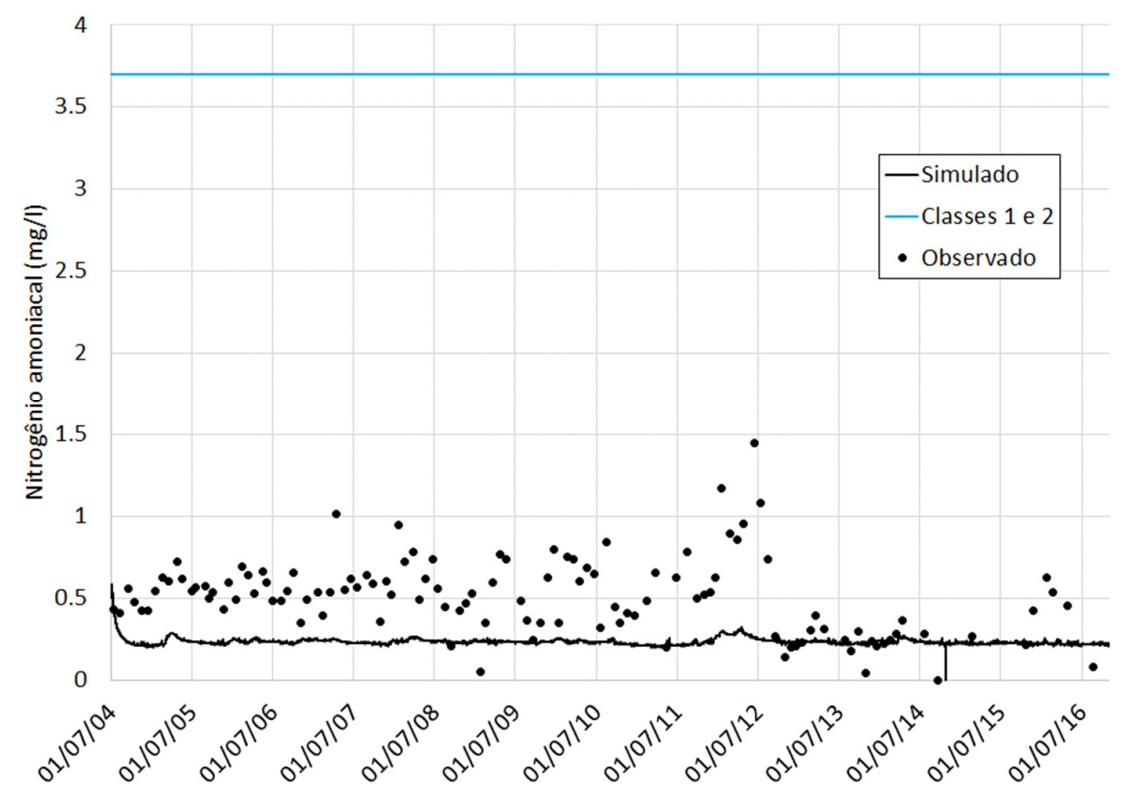

Figura 27. Resultados do modelo junto à barragem e limite da classe 1

Também nesse caso, embora o modelo leve a concentrações inferiores às medidas, essa inconsistência não tem maiores implicações práticas, uma vez que os valores para nitrogênio amoniacal são muito baixos, compatíveis com a classe 1.

Deve-se lembrar que também nesse caso, em vários dos pontos amostrados foi necessário estimar uma partição entre nitrogênio total e nitrogênio amoniacal.

A Figura 28 mostra o resultado para o parâmetro nitrato, no ponto de monitoramento próximo à barragem. Resultados similares foram obtidos para os braços. 


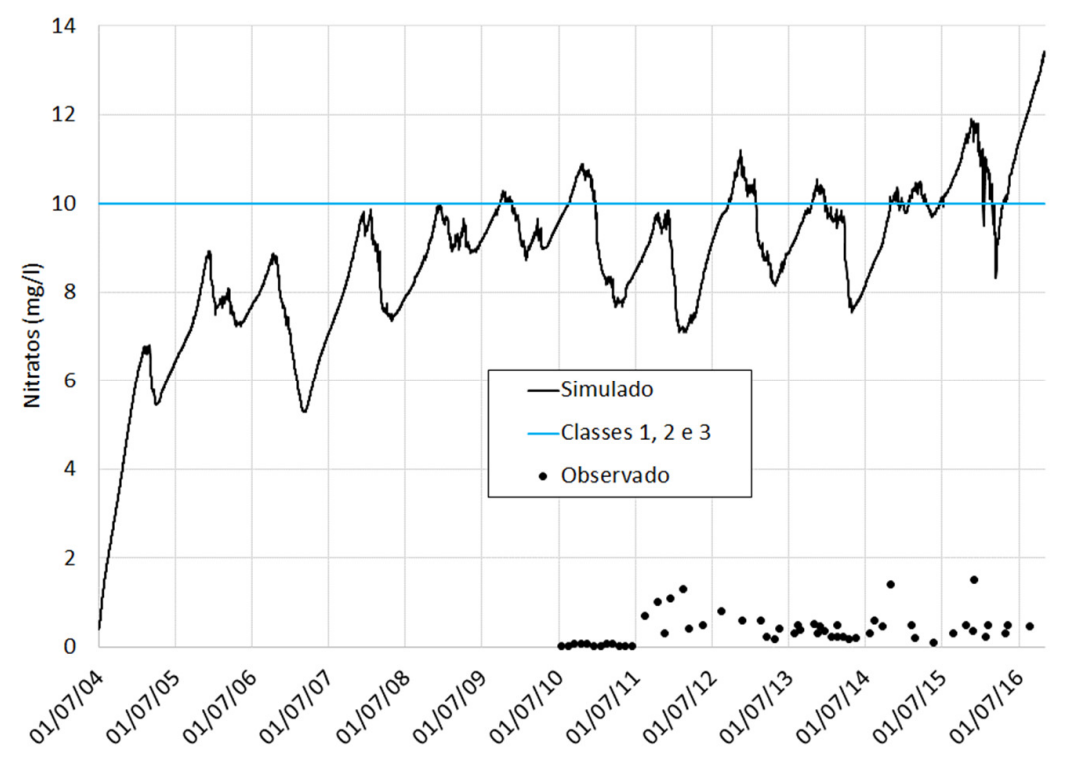

Figura 28. Resultados para o nitrato no ponto próximo à barragem

Observa-se que os resultados para este parâmetro foram bastante ruins. De forma geral as concentrações simuladas foram uma ordem de grandeza superiores às medidas. De fato, aparentemente as concentrações estão crescendo indefinidamente, não tendo encontrado um ponto de equilíbrio, mesmo ao longo de mais de 10 anos de simulação. Neste caso, o erro associado ao modelo tem implicações práticas, uma vez que levaria a concentrações fora da classe em que efetivamente se encontra o manancial. A esse respeito, é importante lembrar que o nitrato é causador de doenças gestacionais.

O nitrato é a última forma possível no ciclo do nitrogênio, no modelo HEC-RAS. Assim, excessos de nitrogênio em outras formas acabam levando a um excesso nesse parâmetro. A explicação mais provável para esse mau resultado é uma inconsistência na real concentração de algas, conforme já mencionado anteriormente. As algas são fontes de nitrogênio, e caso haja um desbalanço na representação de sua biomassa no modelo, isso acaba por afetar os demais ciclos de nutrientes. Possivelmente, alguns parâmetros de conversão das formas de nitrogênio foram distorcidos para melhorar o ajuste de nitrogênio orgânico e amoniacal, por exemplo, levando os excessos a acumularem na forma de nitrato.

Seja como for, este aspecto ainda merece estudos mais aprofundados para a melhor compreensão das incertezas do modelo. 


\subsubsection{Fósforo}

Para simplificação, os resultados foram agrupados na soma de fósforo orgânico e ortofosfato, uma vez que a resolução CONAMA 357/2005 só possui limites para esse parâmetro. A Figura 29 mostra os resultados para o ponto de monitoramento próximo à barragem

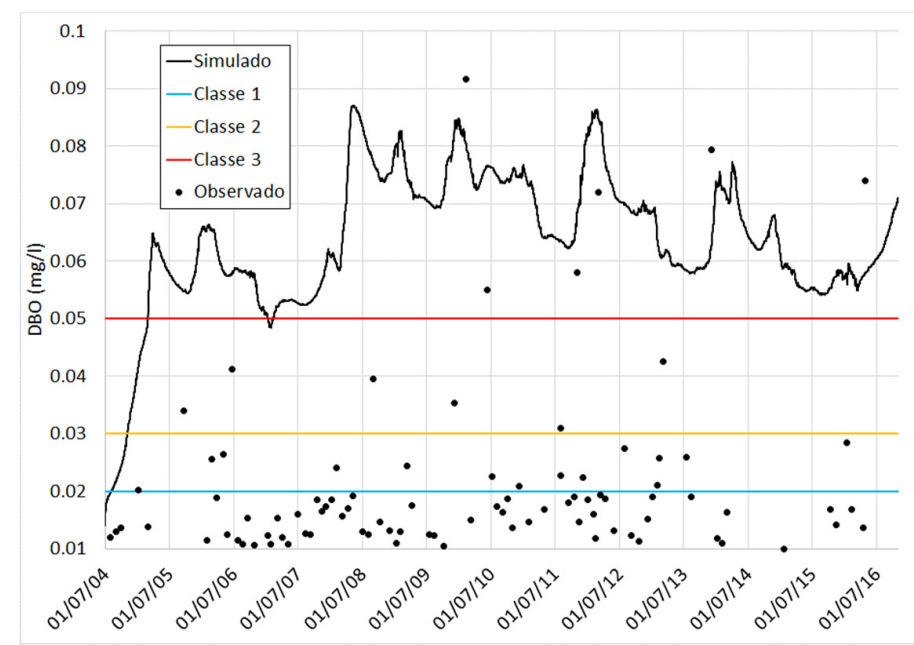

Figura 29. Resultado para o parâmetro fósforo total (orgânico+ortofosfato) próximo à barragem

No caso do fósforo, há uma tendência do modelo superestimar as concentrações, embora pontualmente ocorram medições bastante próximas do que foi simulado. Também nesse caso, as incertezas do modelo têm consequências práticas, uma vez que o manancial seria classificado predominantemente como de classe 4, enquanto a maior parte das medições sinaliza para classe 1 ou 2.

Também neste caso, os problemas parecem residir na concentração de algas, uma vez que estas consomem e produzem fósforo.

\subsubsection{Síntese dos resultados}

A Tabela 3mostra uma síntese dos resultados médios nos diferentes braços e para diferentes parâmetros, mostrando as concentrações médias simulada e observada para cada parâmetro, bem como a diferença percentual entre essas médias. 
Tabela 3. Síntese dos resultados

\begin{tabular}{|c|c|c|c|c|c|c|c|c|c|c|c|c|c|c|c|}
\hline & \multicolumn{3}{|c|}{ Torto } & \multicolumn{3}{|c|}{ Bananal } & \multicolumn{3}{|c|}{ Gama } & \multicolumn{3}{|c|}{ R. Rundo } & \multicolumn{3}{|c|}{ Paranoá } \\
\hline & Simulado & Observado & Dif\% & Sim. & Obs. & Dif\% & Sim. & Obs. & Dif\% & Sim. & Obs. & Dif\% & Sim. & Obs. & Dif\% \\
\hline Temp & 23,4 & 24,5 & $-5 \%$ & 25,0 & 24,5 & $2 \%$ & 24,9 & 24,9 & $0 \%$ & 23,6 & 25,0 & $-6 \%$ & 25,0 & 23,5 & $6 \%$ \\
\hline OD & 6 & 1 & $-7 \%$ & 6,6 & 7,2 & $-9 \%$ & 6,2 & 1 & $-13 \%$ & 5,8 & 6,9 & $-16 \%$ & 6,6 & 5,4 & $21 \%$ \\
\hline DBO & 1,5 & 1,9 & $-20 \%$ & 0,3 & 2,2 & $-86 \%$ & 0,7 & 2,0 & $-64 \%$ & 1,9 & 2,5 & $-23 \%$ & 0,3 & 1,8 & $-83 \%$ \\
\hline Algas & 0,03 & 0,14 & $-78 \%$ & 0,07 & 0,24 & $-72 \%$ & 0,10 & 0,17 & $-38 \%$ & 0,13 & 0,39 & $-68 \%$ & 0,07 & 0,12 & $-45 \%$ \\
\hline$N_{\text {orgânico }}$ & 0,48 & 0,47 & $3 \%$ & 0,22 & 0,61 & $-64 \%$ & 0,31 & 0,69 & $-55 \%$ & 1,12 & 1,16 & $-3 \%$ & 0,22 & 0,52 & $-58 \%$ \\
\hline$N_{\text {amoniacal }}$ & 0,44 & 0,34 & $31 \%$ & 0,23 & 0,44 & $-46 \%$ & 0,39 & 0,54 & $-29 \%$ & 0,75 & 1,12 & $-33 \%$ & 0,23 & 0,51 & $-54 \%$ \\
\hline Nitrato & 2,91 & 0,33 & $781 \%$ & 8,69 & 0,38 & $2157 \%$ & 8,20 & 0,48 & $1613 \%$ & 3,97 & 0,65 & $512 \%$ & 8,69 & 0,39 & $2108 \%$ \\
\hline Nitrito & 0,18 & 0,11 & $66 \%$ & 0,14 & 0,02 & $461 \%$ & 0,22 & 0,02 & $1001 \%$ & 0,36 & 0,01 & $2896 \%$ & 0,14 & 0,01 & $1062 \%$ \\
\hline Porgânico & 0,019 & 0,004 & $401 \%$ & 0,032 & 0,004 & $690 \%$ & 0,038 & 0,003 & $995 \%$ & 0,033 & 0,007 & $358 \%$ & 0,032 & 0,008 & $293 \%$ \\
\hline Ortofosfato & 0,014 & 0,011 & $28 \%$ & 0,031 & 0,013 & $134 \%$ & 0,025 & 0,010 & $142 \%$ & 0,045 & 0,022 & $110 \%$ & 0,031 & 0,009 & $231 \%$ \\
\hline
\end{tabular}




\subsection{Cenários}

A mostra o resultado da simulação do cenário de retiradas de água do Lago Paranoá, no Ribeirão Bananal e no braço do Torto. Os resultados de qualidade de água neste cenário foram comparados com o resultado de referência, resultante da calibração do modelo. Assim, os resultados devem ser encarados em termos relativos (variação em relação ao cenário de referência) e não absolutos (não é possível confiar em concentrações numéricas absolutas, devido às incertezas do modelo).

As maiores variações na qualidade de água, como esperado, foram encontradas nos braços do Bananal e do Torto, que são os mais diretamente afetados pelas captações pretendidas. No ponto próximo à barragem, também houve variações, enquanto nos braços do Riacho Fundo e Gama as alterações foram imperceptíveis.

Somente alguns gráficos representativos serão apresentados, sendo que o modelo gera resultados a cada seção, para cada parâmetro distinto. A Figura 30 mostra a variação prevista pelo modelo para os parâmetros oxigênio dissolvido e concentração de algas no braço do Bananal.

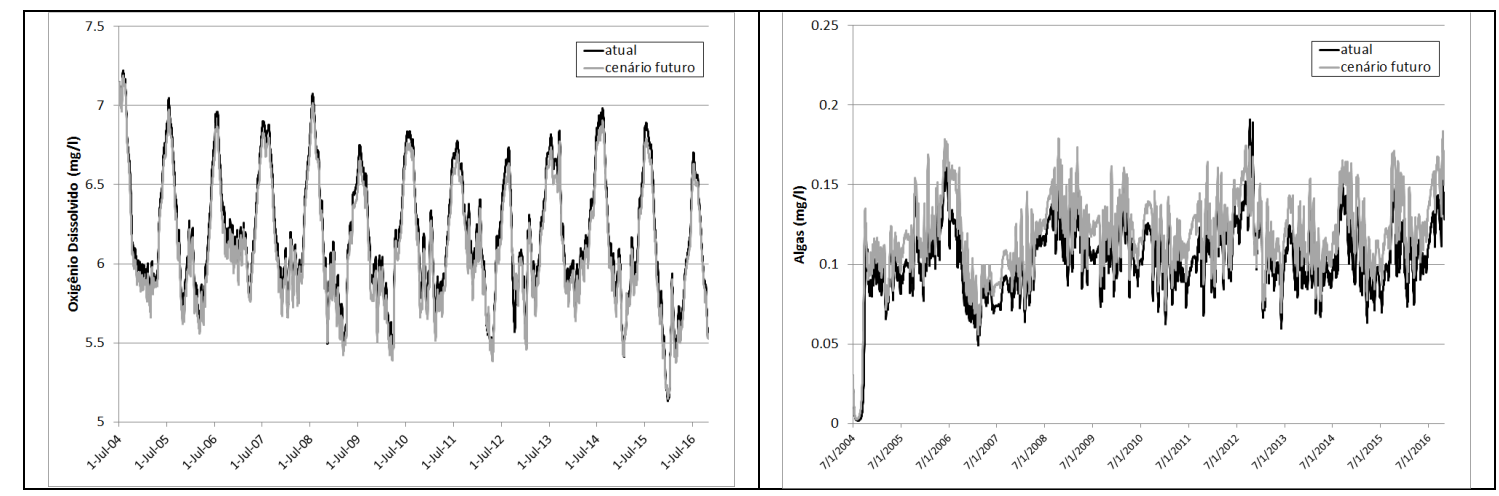

Figura 30. Impacto das captações pretendidas sobre o oxigênio dissolvido (e) e algas (d) no braço do Bananal

Os resultados do modelo indicam que pode-se esperar uma leve diminuição dos teores de oxigênio dissolvido no braço do Bananal. A diminuição média estimada foi de somente 1\%.Já para a concentração de algas o modelo indica um aumento médio de $12 \%$. Este resultado foi o mais expressivo, sendo que os aumentos para os parâmetros de nitrogênio e fósforo foram inferiores a 5\%, e para DBO ocorreu inclusive uma diminuição das concentrações, resultado para o qual não se encontrou uma explicação razoável até o momento.

No caso do braço do Torto, os impactos preditos pelo modelo foram ainda menores. Houve um leve aumento na concentração média prevista de DBO. 


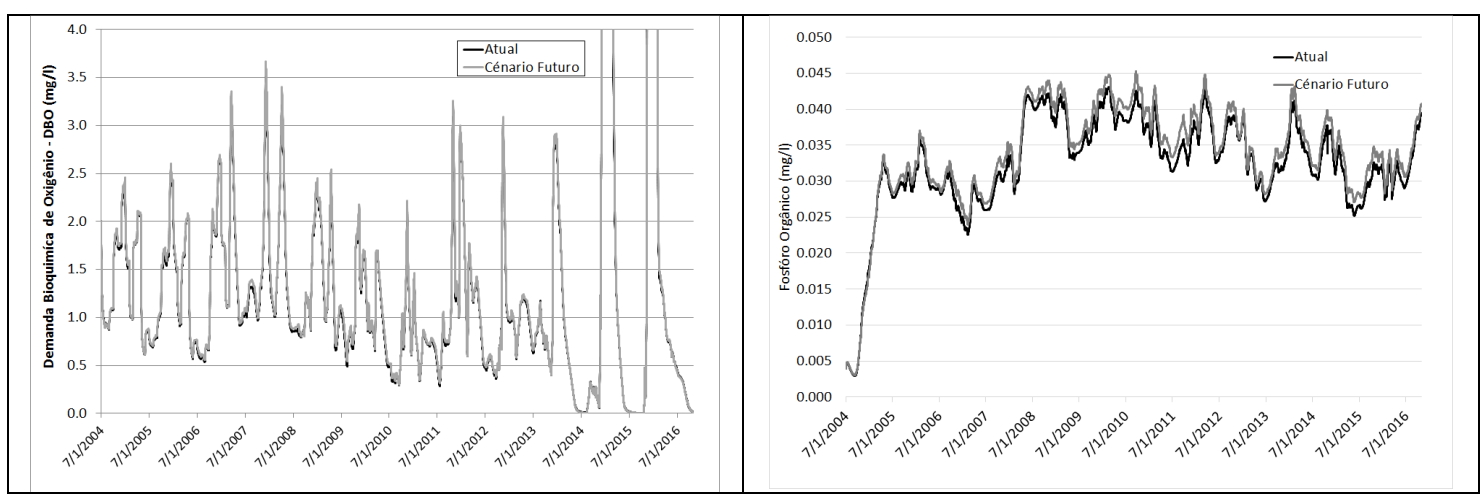

Figura 31. Impacto das captações sobre a DBO no braço do Torto (e) e sobre o fósforo orgânico próximo à barragem

No caso do Torto, houve um pequeno aumento de $1 \%$ na DBO média prevista, enquanto os outros parâmetros apresentaram valores médios iguais ou até inferiores. A melhoria da qualidade de água decorrente de uma captação de água não era um resultado esperado. Uma explicação possível é que a retirada de água neste braço acaba por retirar também os poluentes existentes, e a água é reposta por água mais limpa oriunda dos trechos mais a jusante. Este resultado também precisaria ser melhor explorado. De qualquer forma, os resultados do modelo indicam variações pequenas da qualidade de água.

No braço do Paranoá, houve aumentos pontuais em alguns parâmetros, da ordem de $5 \%$ em média para nutrientes (nitrogênio e fósforo). Para os demais parâmetros, a variação foi inferior a $2 \%$.

Como dito, nos demais braços (Gama e Riacho Fundo) o modelo não indicou qualquer mudança da qualidade de água, decorrente das captações pretendidas.

\section{Considerações finais}

No presente trabalho, aplicou-se um modelo unidimensional de qualidade de água ao Lago Paranoá, reservatório artificial situado no Distrito Federal, com vistas a uma melhor compreensão dos processos quali-quantitativos e à simulação de cenários futuros de uso de água e de ocupação da bacia hidrográfica.

Uma grande quantidade de dados foi necessária para a construção desse modelo, os quais foram obtidos junto a diferentes órgãos públicos. Incluem-se aí dados de quantidade e qualidade de água, no lago e nos tributários, bem como dados de nível d'água do lago, dados meteorológicos e informações sobre a geometria do fundo do lago. Estes dados foram obtidos 
principalmente junto à CAESB, ADASA, ANA, INMET e CEB. Pode-se dizer que a bacia hidrográfica é bem monitorada, em comparação com outras bacias brasileiras, sinalizando para a importância desse manancial para essas diferentes instituições e para a sociedade. Essa boa densidade espacial e temporal de monitoramento contribuiu decisivamente para uma melhoria dos resultados obtidos com o modelo. No entanto, mesmo com essa boa disponibilidade de dados, estes ainda não são suficientes para a simulação no modelo escolhido, de forma que foi necessário adotar diversas premissas para inserção dos dados, premissas que não necessariamente são verdadeiras e que têm impacto sobre os resultados finais.

Na etapa de calibração, foram ajustados diversos parâmetros que controlam fenômenos de qualidade de água, de forma a obter uma aderência entre as simulações e os dados observados nas diversas seções do lago. Conseguiu-se razoáveis ajustes para os parâmetros de temperatura, fósforo, oxigênio dissolvido, DBO, nitrogênio amoniacal e nitrogênio orgânico. Entretanto, o modelo ainda apresenta grandes incertezas na simulação de nitrato e nitrito, levando a concentrações muito mais altas do que efetivamente observado.

Possivelmente as inconsistências para estes parâmetros se devam às premissas adotadas, principalmente quanto à real concentração de algas presente na água do lago. Como mencionado, não se dispõe de medições desse parâmetro, nem no lago nem nos tributários, de forma que foi necessário arbitrar uma relação entre a concentração de algas e a de clorofila, sendo que mesmo desta última o número de medições é extremamente limitado. 0 valor adotado para essa relação tem muito impacto em todos os aspectos do modelo, uma vez que a fisiologia das algas está ligada à concentração de vários outros parâmetros, em especial os nutrientes e o oxigênio dissolvido, o que por sua vez afeta outros parâmetros como a DBO.

No presente caso, possivelmente a relação adotada entre algas e clorofila esteja superestimada, levando a uma concentração de algas no modelo superior à realidade. Com isso, há um aumento da concentração de nitrogênio orgânico pela respiração algal, o que por sua vez obriga a aumentar os parâmetros que controlam a conversão em amônio, e deste em nitrato/nitrito, o que explicaria as altas concentrações simuladas para estes últimos parâmetros. Em outras palavras, a inconsistência de algumas premissas levou a um desequilíbrio do modelo como um todo. 
Assim, uma eventual recomendação para futuros trabalhos seria de tentar repetir as calibrações, porém variando a relação arbitrada entre algas e clorofila, com o intuito de equilibrar melhor os ciclos de nitrogênio, fósforo e oxigênio. No entanto, o mais correto seria incrementar o monitoramento de qualidade de água do lago e dos afluentes, de forma a contemplar também a medição da concentração de massa algal. Essa recomendação também faz sentido devido aos recentes episódios de floração de algas (cianobactérias) no braço do Riacho Fundo, e ao impacto que esse fenômeno tem no uso múltiplo da água e nos ecossistemas do lago.

Em parte, as limitações do modelo podem ser explicadas pelo caráter altamente tridimensional do lago em alguns trechos, notadamente nas seções mais profundas próximas à barragem. Isso pôde ser constatado também pelo fato de o ajuste em geral ter sido bom nos braços, porém não tão bom próximo à barragem, onde o lago é mais profundo.

Uma outra possível melhoria a ser implementada no modelo é considerar de forma simplificada o aporte incremental das áreas não monitoradas. As vazões inseridas nas condições de contorno são monitoradas em 5 estações fluviométricas, cuja área de drenagem totaliza $693 \mathrm{~km}^{2}$, enquanto a área de drenagem do Lago Paranoá junto à barragem é de 1015 $\mathrm{km}^{2}$. Ou seja, certamente há um aporte adicional de água que não foi considerado, o qual poderia ser estimado por meio de uma extrapolação simples por área de drenagem, por exemplo. O aporte adicional de água com temperatura similar à dos tributários provavelmente contribuiria para um melhor ajuste da temperatura da água no modelo.

Os desenvolvimentos e melhorias recomendados aqui estavam previstos em uma proposta de continuação do presente projeto por mais um ano, no âmbito do Programa de Iniciação Científica (PIC) do UNICEUB, conjuntamente com a idéia de transformar o modelo em um sistema de alerta para futuros episódios de floração de algas. Infelizmente, tal proposta não foi selecionada no edital 2017, interrompendo o desenvolvimento dessa linha de pesquisa que começava a dar resultados.

Por fim, o modelo ajustado foi usado para simular o impacto, sobre a qualidade de água do lago, das retiradas de água para abastecimento urbano da CAESB, que se encontram atualmente em construção. Os resultados do modelo indicam que as captações pretendidas no ribeirão Bananal e no braço do Torto causam pouca variação da qualidade de água. As maiores variações foram encontradas no braço do Bananal, onde o resultado mais crítico indicou um aumento de cerca de $17 \%$ na concentração média de fósforo orgânico, além de 
aumentos menores na concentração de algas e nitrogênio (em suas diferentes formas). Este resultado é compreensível, visto que nesse braço encontra-se a ETE Norte, e também devido ao fato de a captação se dar no tributário e não no braço, diminuindo a diluição de efluentes. No braço do Torto, as variações foram menores, ocorrendo aumentos de somente $1 \%$ na DBO e inclusive com diminuição da concentração de nutrientes.

Nos braços mais afastados das intervenções, como o Riacho Fundo e o Córrego do Gama/Cabeça de Veado, os resultados do modelo apontam que as alterações na qualidade de água foram imperceptíveis. Somente no trecho do lago próximo à barragem houve um aumento de $5 \%$ estimado na concentração de algas e de fósforo. De forma geral, os resultados indicam que as captações não provocam mudança da classificação do lago Paranoá, em termos da resolução CONAMA no 357/2005.

\section{Bibliografia}

ANA, 2009: Resolução no158, de 30 de março de 2009. Disponível em http://arquivos.ana.gov.br/resolucoes/2009/158-2009.pdf - Consulta em 18/08/2017

CAESB, 2016: Estações de tratamento de esgoto. Disponível em https://www.caesb.df.gov.br/esgoto/conheca-as-unidades.html - consultado em 20/04/2015

CHOW, Ven Te et al. (1953) Frequency analysis of hydrologic data with special application to rainfall intensities. University of Illinois at Urbana Champaign, College of Engineering. Engineering Experiment Station., 1953.

COLLISCHONN, Walter (2001). Simulação hidrológica de grandes bacias. Teste de Doutorado. Programa de Pós-Graduação em Engenharia de Recursos Hídricos e Saneamento Ambiental, Universidade Federal do Rio Grande do Sul. Instituto de Pesquisas Hidráulicas 270p, Porto Alegre, 2001. 
Congresso em Foco (2017): Paranoá: água para beber? Disponível em http://congressoemfoco.uol.com.br/opiniao/colunistas/paranoa-agua-para-beber/ - consulta em 18/08/2017.

DRAKE, J. BRADFORD, A. JOY, D. Application of HEC-RAS 4.0 temperature model to estimate groundwater contributions to Swan Creek, Ontario, Canada. Journal of Hydrology V.389 Issues 3-4, Ontario -Canada, P 390-398, Ago 2010.

ENVIRONMENTAL AND HYDRAULIC LABORATORIES (1986). A numerical two-dimensional laterally averaged model for hydrodynamics and Water Quality: User's manual. Instruction report E-86-5, U.S. Army Engineer Waterways Experiment Station, Vicksburg, MS.

FRAGOSO JR., C.R., COLLISCHONN, W. \& MOTTA MARQUES, D.M.L., (2007). Simulação ecológica e os estados alternativos em lagos, estuários e reservatórios. In Anais do XVII Simpósio Brasileiro de Recursos Hídricos, São Paulo, Nov. 2007

LARENTIS, D. G. (2004) Modelagem matemática da qualidade da água em grandes bacias: Sistema Taquari-Antas-RS (2004). 177 f. Dissertação (Mestrado de Engenharia) \pm Universidade Federal do Rio Grande do Sul, Porto Alegre, 2004.

Liporoni, Lucas (2012). Estudo preliminar da qualidade de água do Lago Paranoá utilizando um modelo bidimensional de qualidade de água. Dissertação de Mestrado, PTARH/UNB, $188 p$.

Minoti, R. Koide, S. Liporoni, L. (2011). Estimativa das cargas de sedimentos e nutrientes em duas sub-bacias do Lago Paranoá (Brasília/DF). XIX Simpósio Brasileiro de Recursos Hídricos, ABRH, Maceió, 27 de novembro a 1 de dezembro.

Philomeno, M. (2007). A comunidade fitoplanctônica e a restauração do Lago Paranoá, Brasília-DF. Tese de Doutorado, Programa de Pós-Graduação em Ecologia, Universidade de Brasília, 223p. 
ROSMAN, P. C. C. (1989) Modelos de circulação em corpos d'água rasos. In.: Métodos Numéricos em Recursos Hídricos 1. Editora da ABRH,

ROSMAN, P.C.C. (2000) SisBAHIA-Sistema Base de Hidrodinâmica Ambiental, Documentação de Referência Técnica (2000). Área de Engenharia Costeira e Oceanográfica, Universidade Federal de Rio de Janeiro (COPPE-PEnO/UFRJ), Rio de Janeiro, 2000.

SAUTCHUK, Jaime. Cruls: Histórias e Andanças do cientista que inspirou JK a fazer Brasília. São Paulo: Geração editorial, 2014.

TSCHIEDEL, A. (2013) Simulação de Qualidade da Água para Cenários Futuros através do Modelo Qual2K: Um Estudo de Caso para o Rio Macaé, RJ. Porto Alegre, 135 p., 2013. Trabalho de Conclusão de Curso (Graduação em Engenharia Ambiental) - Universidade Federal do Rio Grande do Sul.

TUCCI, C. E. M. Modelos Hidrológicos. 1988. 668 f. Ed. Universidade Federal do Rio Grande do Sul, Associação Brasileira de Recursos Hídricos, Porto Alegre, 1988.

USACE, 2010: HEC-RAS - River Analysis System - User's Manual Version 4.1

USACE, 2015: HEC-RAS - River Analysis System - User's Manual Version 5.0 